\title{
Chinese clinical studies for pharmacological treatments of coronavirus disease 2019 (COVID-19)
}

Ru HAN ${ }^{1,2 \&}$, Yitong WANG ${ }^{1,2 \&}$, Monique DABBOUS ${ }^{1,2}$, Shuyao LIANG ${ }^{1,2}$, Tingting QIU ${ }^{1,2}$, Mondher TOUMI ${ }^{1,2}$

${ }^{\&}$ Ru HAN and Yitong WANG contributed equally to this work.

\author{
${ }^{1}$ University of Aix-Marseille, Marseille, France; \\ ${ }^{2}$ Creativ-Ceutical, Paris, France;
}

Corresponding author: Mondher TOUMI, mondher.toumi@univ-amu.fr

Address: Aix Marseille University, Public Health Department, 27, bd Jean Moulin, 13385 Marseille Cedex 05, France 


\section{Abstract \\ Objectives}

This study aims to identify, report, and analyze registered and published clinical trials and observational studies for the pharmacological treatment of COVID-19 conducted in China.

\section{Methods}

A strategic search was conducted via the Chinese Clinical Trial Registry to identify and extract clinical trials and observational studies registered and conducted in China for the pharmacological treatment of COVID-2019 between January $1^{\text {st }}, 2020$ and March 21 ${ }^{\text {st }}, 2020$. This was further supplemented by searches conducted via the China National Knowledge Infrastructure (CNKI) database, the MEDLINE database, the World Health Organization (WHO) database, and MedRxiv and BioRxiv electronic platforms for preprint articles, published up until April $8^{\text {th }}, 2020$. Studies available in Chinese and English were included in the searches and extracted. A primary descriptive analysis was performed for registered clinical trials and observational studies identified in the Chinese Clinical Trial Registry based on the extraction of the following clinical study information: trial ID, planned date of enrollment, recruitment status, study design, population, sample size, intervention/exposure group, control /reference group, dosage, and primary outcomes. A secondary descriptive analysis was performed for published clinical trials and observational studies identified from the supplementary databases based on the extraction of the following published clinical study information: study design, population, intervention/exposure group, control/reference group and main results as appropriate.

\section{Results}

A total of 221 clinical trials and observational studies were included from all databases searched. From the Chinese Clinical Trial Registry, 195 registered clinical studies including 170 clinical trials and 25 observational studies were identified and included for primary analysis. From the supplementary databases, 26 published clinical studies including 8 clinical trials and 18 observational studies were included for secondary analysis. Of these 26 published clinical studies, 18 studies, including 3 clinical trials and 15 observational studies were identified from CNKI, 2 studies including 1 clinical trial and 1 observational study from MEDLINE, 2 including 1 clinical trials and 1 observational studies from the WHO database, and 4 including 3 clinical trials and 1 observational studies from MedRxiv and BioRxiv platforms. In the primary analysis, among the 170 clinical trials included from the Chinese Clinical Trial Registry, 101 investigated western medicines (WMs), while 15 investigated Traditional Chinese Medicines (TCMs), and 54 investigated a combination of TCMs and WMs. Among the 25 included observational studies from the Chinese Clinical Trial Registry, 2 investigated WMs, 2 investigated TCMs, and 21 investigated a combination of TCMs and WMs. The total number of exposed patients in all 195 clinical studies from the Chinese Clinical Trial Registry amounted to 24,500. In the secondary analysis, treatment with Lopinavir-ritonavir and treatment with Hydroxychloroquine was not associated with a difference from standard of care in the rate of RT-PCR negativity; treatment with a combination of Lopinavir-ritonavir, interferon $\alpha$, and Lian-Hua-Qing-Wen capsule was found to significantly improve the effective rate of treatment compared with Interferon a combined with Lian-Hua-Qing-Wen capsule.

\section{Conclusions}

China is generating a massive source of evidence that is critical for defeating the COVID-19 pandemic. Not only the clinical experience, but also the scientific evidence should be shared with the global scientific community. 
Key words: COVID-19, clinical studies, China, clinical trials, observational studies 


\section{Introduction}

By the end of December 2019 China announced the identification of a new emerging viral condition [1], caused by a novel coronavirus. The virus was provisionally named 2019-coronavirus (2019-nCoV) [2] and then finally named as severe acute respiratory syndrome coronavirus 2 (SARS-CoV-2). The disease, itself, has been officially named as Coronavirus Disease 2019 (COVID-19). Initially confined to the Hubei Province, a specific region of China, the virus spread outside of China to such an extent that on March $12^{\text {th }}, 2020$, the World Health Organization (WHO) declared a COVID-19 pandemic [3]. COVID19 spread across Asia [4], followed by Europe, and finally reached the United States (US), spreading to a degree that led WHO to suggest the US as the new focal point of the pandemic [5]. In China, 82,230 patients have been identified as infected by SARS-COV-2 and 3,301 have died as of the $29^{\text {th }}$ of March 2020[6]. The global mortality was estimated by WHO to be about $3.4 \%$ on March $3^{\text {rd }}, 2020$. By comparison, the seasonal flu generally kills far fewer than $1 \%$ of those infected [7]. Although the mortality is unknown as the denominator is impossible to assess the absolute number of deaths and the majority of patients survive. The cruise liner, the Diamond Princess, may represent a very interesting and informative case of epidemic analysis. Out of approximately 3,500 cruise passengers, 712 were infected and 10 died, resulting in a mortality rate of $1.4 \%$ [6]. However, this should be considered as a high range as it is important to note that these patients were older than the average population and likely suffering from comorbid conditions.

The proliferation of COVID-19 cases was controlled in China, resulting in no reports of new domestic cases as of the $18^{\text {th }}$ of March 2020. High risk patients have been defined as patients above 65 years of age and patients of any age having serious underlying medical conditions, including chronic lung disease, moderate to severe asthma, serious heart conditions, compromised immune systems, severe obesity (body mass index >40), diabetes, and renal failure or liver disease [8]. Currently, at the time of this publication drafting, the outbreak is under control in China, while in Europe and US, the disease has not yet peaked and already 70,459 and 20,601 patients have died, respectively [8]. China has gained experience by treating COVID-19 patients and by conducting clinical trials.

The objective of this manuscript was to identify, report, and analyze registered and published clinical trials and observational studies for the pharmacological treatment of COVID-19 conducted in China. Given that COVID-19 emerged in China and that the Chinese have managed to control the outbreak, with what will likely be a significantly lower number of deaths than in Europe and the United States (US) according to current predictions, supports the importance in gaining insight from these clinical trials and observational studies conducted in China.

\section{Method}

A strategic search was conducted via the Chinese Clinical Trial Registry and supplemented by searches conducted via the China National Knowledge Infrastructure (CNKI) database, the MEDLINE database, the World Health Organization (WHO) database, and MedRxiv and BioRxiv electronic platforms for preprint articles to identify and extract clinical trials and observational studies conducted in China for the pharmacological treatment of COVID-2019. A primary and secondary descriptive analysis for registered and published clinical studies were performed, respectively. The strategic search of the Chinese Clinical Trial Registry was conducted using the keyword "novel coronavirus" to identify both clinical trials and observational studies registered between January 1st, 2020 and March 25th, 2020. Results from the Chinese Clinical Trial Registry search were included if they met the following inclusion criteria: 1) they were clinical trials or observational studies, 2)the intervention in clinical trials and the exposures in observational studies were pharmacological strategies for the treatment of COVID-19, and 3) they were currently registered in China. 
A primary descriptive analysis was performed for registered clinical trials and observational studies identified from Chinese Clinical Trial Registry based on the extraction of the following clinical study information: trial ID, planned date of enrollment, recruitment status, study design, population, sample size, intervention/exposure group, control /reference group, dosage, and primary outcomes. Pharmacological interventions and/or exposures were classified as Western Medicines (WMs), Traditional Chinese Medicines (TCMs), and a combination therapy of WMs and TCMs. WMs were further stratified into antiviral agents, antiparasitic agents, anti-inflammatory agents, biologics, cellbased therapies, plasma therapies, other therapies, and combination therapies of WMs with different mechanisms of action.

The strategic searches of the supplementary databases, CNKI, MEDLINE, WHO, and MedRxiv and BioRxiv platforms, were conducted by employing the following keywords: 1) for the CNKI database: "novel coronavirus", "2019-nCoV", "COVID-19" and "SARS-CoV-2"; 2) MEDLINE: "novel coronavirus" AND "clinical studies", "trials", "observational studies"; 3) WHO database and preprint platforms with all included paper in pharmacology-related subject area. Results from the supplementary database searches were included if: 1 ) they met the three inclusion criteria also applied to the Chinese Clinical Trial Registry and 2) if they reported study results. A secondary descriptive analysis was performed for published clinical trials and observational studies identified from supplementary databases based on the following extracted clinical study publication information: study design, population, intervention/exposure group, control/reference group and main results as appropriate. The rationale for the use of WMs reported in the included clinical studies for COVID-19 was reported based on published reviews [9] and electronic reports $[10,11]$.

No quality assessment was performed. Two researchers independently conducted the searches and extracted information. Any discrepancies identified between the two researchers were reconciled by a third, independent researcher.

\section{Results}

A total of 221 clinical trials and observational studies for pharmacological treatments of COVID-19 were included from all databases searched. From the Chinese Clinical Trial Registry, 195 registered clinical studies, including 170 clinical trials and 25 observational studies, were identified and included for primary analysis. From the supplementary databases, 26 published clinical studies, including 8 clinical trials and 18 observational studies, were included for secondary analysis. Of these 26 published clinical studies, 18 published clinical studies were identified and included from the CNKI, including 3 clinical trials and 15 observational studies, 2 from MEDLINE, including 1 clinical trial and 1 observational study, from MEDLINE, 2 from WHO, including 1 clinical trial and 1 observational study, and 4 clinical studies, including 3 clinical trials and 1 observational study from MedRxiv and BioRxiv electronic platforms. A total of $43 \mathrm{WMs}$ and $42 \mathrm{TCMs}$ were identified in this study and the rationale for WMs in the treatment of COVID-2019 was summarized in Table 1.

\subsection{Primary analysis for registered clinical studies from the Chinese Clinical Trial Registry Results}

Of the 482 COVID-19 related studies registered in the Chinese Clinical Trial Registry as of March $21^{\text {st }}$, 2020, a total of 195 clinical studies, comprising of clinical trials $(n=170)$ and observational studies $(n=25)$, were included from the search. The remaining 287 studies were excluded as 1$)$ they were not clinical trials or observational studies $(n=53) ; 2)$ they did not investigate the effect of pharmacological treatment ( $n=189)$; or 3 ) they were cancelled by the investigators in the trial registry $(n=45)$. Of the 170 included clinical trials investigating the pharmacological treatment effects of WMs ( $n=101)$, TCMs $(n=15)$, and a combination therapy of WMs and TCMs $(n=54)$, the sample size ranged from 10 to 1,000 patients. Of the 25 included observational studies investigating the pharmacological treatment effects of WMs $(n=2), \operatorname{TCMs}(n=2)$, and a combination therapy of WMs and TCMs $(n=21)$, the sample size 
ranged from 20 to 2,000 patients. The total number of exposed patients of all the 195 clinical studies included was 24,500 .

\subsubsection{Clinical trials of pharmacological treatments for COVID-19 in China}

Clinical trials of WMs

Of the 101 included trials for WMs, 93 monotherapies were identified, including antivirus agents $(n=20)$, biologics $(n=19)$, antiparasitic agents $(n=16)$, cell-based therapies $(n=11)$, plasma therapies $(n=11)$, anti-inflammatory agents $(n=6)$, other therapies $(n=7)$, and combination therapies of WMs with different mechanisms of action $(n=11)$.

Clinical trials of antivirus agents

Of the 20 included trials for antivirus agents ( 
Table 2), 14 trials were recruiting as planned, while the remaining 6 trials were pending, most trials $(n=12)$ were randomized clinical trials (RCTs) with sample sizes ranging from 30 to 380 patients. Eleven different antivirus agents were investigated, including Lopinavir-ritonavir(n=6), Favipiravir $(n=4)$, Azvudine $(n=4)$, Danorevir Sodium +Ritonavir $(n=3)$, Baloxavir Marboxil $(n=2)$, ASC09-ritonavir $(n=1)$, Darunavir $(n=1)$, Emtritabine + Tenofovir alafenamide Fumarate $(n=1)$, Triazavirin $(n=1)$, Umifenovir $(n=1)$, and LL-37 antiviral peptide $(n=1)$.

Fifteen of the clinical trials reported 1 primary outcome, while 5 clinical trials reported more than 1 primary outcome. Time to reverse transcription polymerase chain reaction (RT-PCR) negativity $(n=7)$, rate RT-PCR negativity $(n=7)$, rate of composite adverse outcomes $(n=4)$, and time to clinical recovery $(n=3)$ were the most reported primary outcomes ( 
Table 2).

\section{Clinical trials of biologics}

Of the 20 included trials for biologics (Table 3), 11 trials were currently recruiting as planned and most trials $(n=17)$ were RCTs with sample sizes ranging from 30 to 328 patients. Seventeen different biologics were investigated, including Tocilizumab $(n=2)$, Enoxaparin Sodium $(n=2)$, Nebulized Heparin-N-acetylcysteine $(n=1)$, Adalimumab $(n=1)$, Adalimumab +Tocilizumab $(n=1)$, Antiprogrammed cell death-1 monoclonal antibody $(n=1)$, Polyinosinic-Polycytidylic Acid $(n=1)$, Probiotics $(n=1)$, Recombinant human granulocyte colony-stimulating factor $(n=1)$, Interferon alpha $\alpha 1 b(n=1)$, Interferon alpha $\alpha 1 b$ Eye Drops $(n=1)$, Recombinant Human Interleukin-2 $(n=1)$, Recombinant viral macrophage inflammatory protein ( $n=1)$, Regulating intestinal flora $(n=1)$, Thymosin $(n=1)$, Ulinastatin $(n=1)$, Camrelizumab ( $n=1)$, and Mycobacterium vaccae injection $(n=1)$.

Eleven of the clinical trials reported 1 primary outcome, while 9 clinical trials reported more than 1 primary outcome. Time to RT-PCR negativity $(n=3)$ and time to clinical recovery $(n=3)$ were the most reported primary outcomes (Table 3 )

\section{Clinical trials of antiparasitic agents}

Of the 16 included trials for antiparasitic agents (Table 4), 11 trials were currently recruiting as planned and most trials $(n=11)$ were RCTs with sample sizes ranging from 10 to 320 patients. Three antiparasitic agents were investigated, including Chloroquine Phosphate $(n=10)$, Hydroxychloroquine $(n=8)$, and Suramin sodium $(n=1)$.

Eleven of the clinical trials reported 1 primary outcome, while 5 clinical trials reported more than 1 primary outcome. Time to RT-PCR negativity $(n=7)$ and time to clinical recovery $(n=5)$ were the most reported primary outcomes (Table 4).

\section{Clinical trials of cell-based therapies}

Of the 11 included trials for cell-based therapies (Table 5), 3 trials were currently recruiting as planned. Most trials $(n=8)$ were RCTs with sample sizes ranging from 16 to 63 patients. Two different cell-based therapies, Mesenchymal stem cells and its exosomes $(n=10)$ and Human natural killer cellsmesenchymal stem cells $(n=1)$, were investigated.

One clinical trial did not report any primary outcomes, 6 clinical trials reported 1 primary outcome, and 4 clinical trials reported more than 1 primary outcome. Chest $C T(n=4)$ and clinical symptoms $(n=2)$ were the most reported primary outcomes (Table 5).

\section{Clinical trials of plasma therapy}

Of the 11 included trials for plasma therapies (Table 6), 9 trials were currently recruiting as planned and most trials $(n=7)$ were RCTs with the sample sizes ranging from 10 to 200 patients. Four different plasma therapies were investigated, including Convalescent plasma ( $n=7)$, Anti-2019-nCoV virus inactivated plasma ( $n=3)$, immunoglobulin of cured patients $(n=1)$, and Umbilical plasma $(n=1)$.

Eight of the clinical trials reported 1 primary outcome, while 3 clinical trials reported more than 1 primary outcome. Clinical symptoms $(n=3)$ and time to clinical improvement $(n=2)$ were the most reported primary outcomes (Table 6).

\section{Clinical trials of anti-inflammatory agents}

Of the 6 included trials for anti-inflammatory agents (Table 7), 4 trials were currently recruiting as planned and most trials $(n=5)$ were RCTs with sample sizes ranging from 16 to 200 patients. Five different anti-inflammatory agents were investigated, including Methylprednisolone $(n=2)$, Corticosteroid $(n=1)$, Jakotinib hydrochloride $(n=1)$, Leflunomide $(n=1)$, and Tranilast $(n=1)$. 
Four of the clinical trials reported 1 primary outcome, while 2 clinical trials reported more than 1 primary outcome. Time RT-PCR negativity $(n=2)$ was the most reported primary outcome (Table 7$)$.

\section{Clinical trials of other WMs}

Of the 6 included trials for other WMs (Table 8), 4 trials were currently recruiting as planned $(n=4)$ and most trials $(n=5)$ were RCTs with sample sizes ranging from 40 to 520 patients. Five drugs were investigated, including Pirfenidone $(n=2)$, Hydrogen Peroxide gargle $(n=1)$, Lipoic acid injection $(n=1)$, Bismuth potassium citrate $(n=1)$, and Carrimycin $(n=1)$.

All of the clinical trials $(n=6)$ reported 1 primary outcome. The rate of RT-PCR negativity $(n=3)$ was the most reported primary outcome (Table 8).

Clinical trials of WM combination therapies

Of the 11 included trials for WM combination therapies (Table 9), 10 trials were currently recruiting as planned and most trials $(n=9)$ were RCTs with sample sizes ranging from 30 to 150 patients. Nine trials investigated the effects of antivirus agents combined with biologics $(n=7)$, an antiparasitic agent $(n=1)$ or a biologic plus anti-inflammatory agent $(n=1)$, while 2 trials investigated 2 cell-based therapies combined with a biologic $(n=1)$ or an anti-inflammatory agent $(n=1)$.

Eight of the clinical trials reported 1 primary outcome, while 3 clinical trials reported more than 1 primary outcome. Chest $\mathrm{CT}(\mathrm{n}=4)$ was the most reported primary outcome (Table 9).

\section{Clinical trials of TCMs}

Of the 15 included trials for TCMs, 9 trials reported the specific names of investigated TCMs. Of these 9 trials, specifying TCMs (Table 10), 4 trials were currently recruiting as planned and most trials $(n=6)$ were RCTs with sample sizes ranging from 60 to 400 patients. Thirteen different TCM compounds were investigated in these 9 trials specifying TCMs.

Five of the clinical trials reported 1 primary outcome, while 4 clinical trials reported more than 1 primary outcome. Clinical symptoms $(n=3)$ was the most reported primary outcome (Table 10 ).

Clinical trials of WM and TCM combination therapies

Of the 54 included trials for WM and TCM combination therapies, 31 trials reported the specific names of investigated TCMs. Of the 31 trials specifying TCMs combined with WMs ( 
Table 11), 21 trials were currently recruiting as planned and most trials $(n=26)$ were RCTs with sample sizes ranging from 20 to 408 patients. Thirty-six different TCM compounds were combined with standard of care (SOC) $(n=33)$, lopinavir-ritonavir $(n=10)$, lopinavir-ritonavir + Interferon $\alpha 2 b(n=1)$, and Umifenovir $(n=1)$ in these 31 trials specifying TCMs.

Twenty-one of the clinical trials reported 1 primary outcome, while 10 clinical trials reported more than 1 primary outcome. Chest CT $(n=8)$, time to clinical recovery $(n=7)$, and clinical symptoms $(n=7)$ were the most reported primary outcomes (Table 11).

\subsubsection{Observational studies of pharmacological treatments for COVID-19 in China}

Of the 25 included observational studies for pharmacological treatments, 6 studies reported the specific names of investigated interventions, while the others $(n=19)$ did not. Two WMs, including antivirus agents plus biologics $(n=1)$ and a cell-based therapy $(n=1)$ were investigated, while 3 TCMs, including Qing-Fei detoxification ( $n=2)$, Triple energizer $(n=1)$, and Xin-Guan-1 formula $(n=1)$ were investigated. Of the 6 observational studies specifying interventions ( 
Table 12), 4 studies were currently recruiting as planned and 1 study was completed. Half of the studies $(n=3)$ were cohort studies with sample sizes ranging from 100 to 237 patients and the other half of studies $(n=3)$ were case series with sample sizes ranging from 20 to 100 patients.

Two of the observational studies reported 1 primary outcome, while 4 observational studies reported more than 1 primary outcome. Chest CT $(n=2)$ and blood routine tests $(n=2)$ were the most reported primary outcomes ( 
Table 12).

3.2 Secondary analysis for published clinical studies from supplementary databases: CNKI, MEDLINE, WHO, and MedRxiv and BioRxiv Platforms

From the supplementary searches of the CNKI, MEDLINE, WHO, and MedRxiv and BioRxiv platforms, a total of 27 published clinical studies, including 8 clinical trials and 19 observational studies were included for secondary analysis. Of the 8 clinical trials, 3 were identified and included from CNKI [1214], 1 from MEDLINE [15], 1 from WHO [16], and 3 from the MedRxiv and BioRxiv platforms [17-19]. Of the 18 observational studies, 15 were identified and included from CNKI [20-34], 1 from MEDLINE [35], 1 WHO database [36], and 1 was from MedRxiv electronic platform [37].

\subsubsection{Published clinical trials from supplementary searches}

Of the 8 included trials (Table 13), all trials were RCTs with sample size ranging from 30 to 240 patients; and 7 different interventions were investigated, including $5 \mathrm{WMs}$ and 2 TCMs combined with WMs. Treatment with Lopinavir-ritonavir $(n=99)$ was not associated with a difference from SOC $(n=100)$ in the time to clinical improvement $(p>0.05)$ and mortality at 28 days $(19.2 \%$ vs. $25.0 \%, p>0.05)$. Treatment with Lopinavir-ritonavir $(n=21)$ or Umifenovir $(n=16)$ was not associated with a difference from SOC with no antiviral drugs $(n=7)$ in time of positive-to-negative conversion of SARS-CoV-2 nucleic acid, the rates of antipyresis, cough alleviation, improvement of chest CT or the deterioration rate of clinical status (all $P>0.05$ ). Treatment with Ribavirin + Lopinavir-ritonavir + Interferon $\alpha(n=21)$ was not associated with a difference from Lopinavir-ritonavir + Interferon $\alpha(n=46)$ in time to RT-PCR negativity and days of hospitalization; treatment with Favipiravir $+\mathrm{SOC}(n=116)$ was associated with a difference from Umifenovir + SOC $(n=120)$ in clinical recovery rate of day $7(71.43 \%$ vs $55.86 \%$, $P=0.0199)$, fever reduction and cough relief $(P<0.001)$; More adverse events $(13.79 \%$ vs $2.50 \%$, $P<0.0001)$; treatment with Hydroxychloroquine $(n=15)$ was not associated with a difference from SOC $(n=15)$ in rate of RT-PCR negativity (86.9\% vs. $93.3 \%$. $p>0.05)$; treatment with Hydroxychloroquine + SOC $(n=31)$ was associated with a difference from SOC $(n=31)$ in time to clinical recovery and proportion of patients with improved pneumonia (80.6\% vs $54.8 \%$ ); treatment with Lopinavirritonavir+ interferon $\alpha+$ Lian-Hua-Qing-Wen capsule $(n=30)$ was found to significantly improve effective rate of treatment $(76.7 \%$ vs. $46.7 \%$, p<0.01) compared with Interferon $\alpha+$ Lian-Hua-QingWen capsule $(n=30)$; and treatment with Tou-Jie-Qu-Wen Granule + Umifenovir $(n=20)$ was found to significantly improve the TCM syndrome score, absolute value of lymphocyte and value of $C$ reactive protein compared with Umifenovir alone ( $n=17)$ (Table 13).

\subsubsection{Published observational studies from supplementary searches}

Of the 18 included observational studies (Table 14), most studies ( $n=14)$ reported the specific name of all investigated interventions in the publications, while the others $(n=4)$ did not report the name of investigated TCMs. Most of the studies $(n=12)$ were retrospective case series with sample sizes ranging from 10 to 463 patients, while the remaining studies $(n=6)$ were retrospective cohort studies with sample sizes ranging from 28 to 134 patients. Twelve different interventions were investigated including $10 \mathrm{WMs}$ and $3 \mathrm{TCMs}$. Treatment with Lopinavir-ritonavir + Interferon $\alpha+$ Symptom treatment $(n=52)$ and Umifenovir + Interferon $\alpha+$ Symptom treatment $(n=34)$ were not associated with a difference from Interferon $\alpha+$ Symptom treatment $(n=48)$ in rate of RT-PCR negativity $(71.8 \%$ vs. $82.6 \%$ vs. $77.1 \%, P=0.79$ ) and a difference in number of patients still in progress ( 22 vs 13 vs 25 , $\mathrm{P}=0.3)$. Treatment with Umifenovir + Lopinavir-ritonavir $(\mathrm{n}=16)$ was associated with a difference from Lopinavir-ritonavir ( $n=17$ ) in the rate of RT-PCR negativity ( $75 \%$ vs $35 \%, P<0.05)$ and chest CT $(69 \%$ vs $29 \%, P<0.05)$; treatment with Meplazumab $+S O C(n=17)$ was associated with a difference from SOC $(n=11)$ in the discharged $(p=0.006)$ and case severity $(p=0.021)$ in critical and severe patients; and 
treatment with Shu-Feng-Jie-Du Capsule $(n=35)$ was found to significantly improve the symptoms and time to RT-PCR negativity $(p<0.05)$ compared with Umifenovir alone $(n=35)$ (Table 14).

\section{Discussion}

A total of 195 clinical studies, comprising of clinical trials $(n=170)$ and observational studies $(n=25)$, were included from the Chinese Clinical Trial Registry. Altogether, 24,500 patients were planned to be exposed in these clinical studies. Among the 170 clinical trials involving 17,151 patients, 101 tested WMs, 15 tested TCMs, and 54 tested a combination of TCMs and WMs. 129 of these were RCTs. Currently, 113 clinical trials were still recruiting, however, it is expected that most studies have finished their enrollment because they have at least run for more than one month and may not take more than three weeks to finalize the enrollment during the period of COVID-19 pandemic outbreak.

The numbers of registered clinical studies and exposed patients in China are very impressive and suggest a massive knowledge has been acquired from China as what is presented in this paper is only clinical experience and does not include the critical experience of radiologists and virology laboratories.

TCMs remain of high interest within the Chinese medical community and despite WMs being studied as well, there is still a significant place for TCMs. However, there were still more WMs and combination therapies of WMs and TCMs being studied than TCMs.

The rationale for testing a specific product or a combination of products is not always provided in clinical trials and observational studies. However, several rationales for the investigation of WMs may be considered in the case of this outbreak, such as interventions that have been shown to be effective with other coronaviruses, SARS-COV-2 in vitro, and other viruses as well as interventions that may control the cytokine release, that are based on Mesenchymal stem cells therapies, and interventions with antibodies from patients already recovered from the disease. In relation to TCMs, one of the main concepts of TCM theory is the balance of Yin and Yang, which have been utilized as interventions against COVID-19 to enhance immune defense, relieve fever, restore biological and physiological imbalance, inhibit virus and bacteria, and reduce the inflammatory response of the body caused by the virus and bacteria in mild and moderate patients as well as to gain time and ultimately rescued patients in sever conditions [38]. TCMs were considered not only as adjuvant therapies but also as curative therapies in the COVID-19 outbreak in China and recommended by Chinese clinical guidelines for COVID-19 issued by the National Health Commission of the People's Republic of China [39].

The gold standard of a clinical trial study design is the double-blinded RCT. The process of developing a golden standard clinical trial is unlikely to be feasible within the context of a pandemic outbreak, due to the several months it usually requires to secure pharmaceutical development quality control testing. Therefore, it may be understandable that the studies conducted were not double blinded. As the majority of trials were randomized, this may still guarantee a high likelihood of comparability between treatment arms of the clinical trials. The comparator in gold standard RCTs is always SOC. It is unclear if SOC has been standardized to be comparable in the trials identified and included in this paper. However, in the context of a pandemic outbreak, specifically COVID-19, the SOC would be to ensure vital functions were maintained, especially respiratory functions. Therefore, SOC among the trials identified and included would likely be very similar, especially due to the vast amount of published guidelines in China for the medical management of COVID-19, specifically in relation to the maintenance of respiratory functions.

It will be important to ensure that concomitant therapies, such as biotherapies, corticosteroids, and non-steroid anti-inflammatory drugs, among others, are proportionally used in comparative arms to 
a reasonable degree. However, it is important that biological, viral analysis, and thoracic imaging are blinded.

In the case of a pandemic outbreaks, such as COVID-19, tensions arise in healthcare systems and strain is placed on the availability of human resources, material resources, and pharmaceuticals. Due to pharmaceutical scarcity, it is possible that clinical trial procedures may not have been fully respected, therefore, potentially introducing biases. However, as several trials were performed for each intervention, a meta-analysis could be performed and may provide robust outcomes integrating the variability of these trials and estimating the effect size of these interventions.

The large number of trials currently registered in China and still open to recruitment, has led to the relative paucity of publications of study results. However, the international scientific community has been eager for the scientific communication and exchange of the large knowledge accumulated in China on the treatment of COVID-19.

It is surprising that WHO has not acted to ensure the expedited dissemination of the continuously accumulating knowledge in China. There is no public evidence of any third party advocating to Chinese authorities to publicly share the vast knowledge accumulated in China.

Other challenges while performing clinical trials for this particular condition is that a large number of patients of patients are asymptomatic and may recover without being aware of their infection statues and, ultimately, without treatment. For mild and moderate patients, SOC followed the guidance of the "Diagnosis and Treatment Protocol for COVID-19 Pneumonia" published by the Chinese National Health Commission [39] has proven to be effective.

Therefore, additional pharmacological treatments other than SOC should be targeted towards to highrisk or very high-risk patients who will eventually end up in intensive care. Treating patients too early may result in a significant number of spontaneously resolved cases, which would require large clinical trial sample sizes to derive conclusions. Treating patients too late may result in the treatment of patients for which the virus is likely cleared, or the inflammatory lesions and bacterial infection as consequences of being infected with the virus will be life threatening. Defining the optimal patient populations and time of enrollment for a COVID-19 trial may be as important as the treatment's effectiveness. Analysis of patient subgroups based on different criteria, including virologic load and further investigation of infection severity level of included patients in clinical trial data may be informative to address these issues.

A great deal of attention has been brought to the possible benefits of chloroquine and derivatives, the broadly used antimalarial drugs. Researchers from the Wuhan Institute of Virology [40] evaluated in vitro 5 FDA-approved drugs and 2 broad spectrum antivirals against a clinical isolate of SARS-CoV-2 and concluded that "chloroquine is highly effective in the control of 2019-nCoV infection in vitro" and that its "safety track record suggests that it should be assessed in human patients suffering from the novel coronavirus disease." Researchers from Wuhan University published a report on the use of hydroxychloroquine and found that, among 80 systematic lupus erythematosus patients treated with hydroxychloroquine, none of them were infected with SARS-CoV-2 during the outbreak.

More recently, researchers from the Shanghai University attributed the ability to control the outbreak of COVID-19 in their hospital to the systematic introduction of chloroquine and hydroxychloroquine beginning on February $5^{\text {th }}, 2019$. Researchers from the Qingdao University indicated that "according to the news briefing, results from more than 100 patients have demonstrated that chloroquine phosphate is superior to the control treatment in inhibiting the exacerbation of pneumonia, improving lung imaging findings, promoting a virus negative conversion, and shortening the disease course." In 
France, a clinical study in Marseille [41] reported a 100\% viral clearance in nasopharyngeal swabs in 6 patients after 5 and 6 days of the combination of hydroxychloroquine and azithromycin. The French Ministry of Health recently allowed the use of hydroxychloroquine to treat COVID-19 disease pending the results of ongoing clinical trials. However, an observational study in Paris [42] reported that repeated nasopharyngeal swabs in 10 patients using a RC-PCR assay were still positive for SARS-CoV2 RNA in 8/10 patients at days 5 to 6 after treatment initiation. Within 5 days, one patient died, two were transferred to the ICU, and one patient discontinued because of cardiotoxicity. In the absence of virologic or clinical benefit of chloroquine in a number of viral infections, the option of using chloroquine in the treatment of SARS-CoV-2 should be examined with attention in light of the recent promising announcements. Two new observational studies from Marseille support the use of hydroxychloroquine in association with Azithromycin [41, 43]. The last one [43] gather data among 1 , 061 treated patients they observed $98 \%$ cure, $4 \%$ of hospitalisation including $1 \%$ in ICU and $0.5 \%$ death . Current death rate in $3.5 \%$ globally and the lowest one in Germany and Korea is $2 \%$.

In Chinese governmental treatment guideline for COVID-19 [44], chloroquine and hydroxychloroquine appeared as the pillar therapy for COVID-19. It remains unfortunate that more knowledge has not been shared about the selection rationale and associated outcome of using hydroxychloroquine at this point on time of the pandemic may severely target Africa. In Africa, the healthcare infrastructure is totally unable to absorb the consequences of a pandemic that will affect up to one-third or more of the population. The experience-based treatment guidelines may not be enough and more evidence must be generated to facilitate the dissemination of not only clinical experience, but also the scientific evidence from China and their ability to overcome the outbreak to the rest of the world.

Physical distancing is unlikely feasible in Africa due to cultural standards and extreme poverty. People currently live with immediate and extended families in a single room housing up to 20 people or more. In large cities and large city suburbs, rooms with several large families are built one next to other with no clear separation of property. It is also common cultural practice and courtesy that when someone falls ill, all the relatives and close friends visit with the ill to check on them and spend time. Most people in Africa are living off of informal work and are paid daily as it is non-contractual. These daily wages feed their large families and they will face the decision as to whether they will respect confinement measures put in place, risking the loss of their daily salary, and, ultimately, being unable to feed their families, or they will leave confinement to work and as a byproduct disseminate the coronavirus. To battle COVID-19, they have been recommended to wash their hands repeatedly while a vast majority do not have access to water and if they do, they must carry it by hand across long distances. Moreover, they have little access to soap. They are recommended to blow their nose in disposable handkerchiefs, which may not even be affordable. They are recommended to sneeze in their elbows while they mostly dress short sleeves during the hot summer season.

Obviously without an effective pharmaceutical that is affordable like hydroxychloroquine or chloroquine a disaster is brewing in Africa and other countries, such as India. The lack of WHO clear recommendations for using the ammunition considered by Chinese as one of the ultimate options to control pandemic may have long term consequence on WHO's credibility in developing countries. Instead WHO continues to provide inapplicable guidance and warns against the use of chloroquine. WHO's credibility has been questioned during the Ebola, Zika, and Chikungunya outbreaks [45].

\section{Conclusion}

China is generating a massive source of evidence that is critical for defeating the COVID-19 pandemic. The authors encourage Chinese scientists to share this knowledge. The knowledge about TCMs is likely difficult to transfer in a short time for an outbreak. It deserves further analysis. Among all tested pharmacological agents, evidence and guidelines in China points toward hydroxychloroquine and 
chloroquine being the effective therapies, but this observation is mainly based on the clinical experience and limited published studies. However, evidence has accumulated ex-China to support the benefit of hydroxychloroquine in the treatment of COVID-19. More evidence is under generation and should be shared with the global scientific community. 


\section{References}

1. Lai, C.C., et al., Severe acute respiratory syndrome coronavirus 2 (SARS-CoV-2) and coronavirus disease-2019 (COVID-19): The epidemic and the challenges. Int J Antimicrob Agents, 2020. 55(3): p. 105924.

2. Huaxia, New-type coronavirus causes pneumonia in Wuhan: expert, in XINHUANET NewS Report.

3. World Health Organization (WHO). Available from: http://www.euro.who.int/en/healthtopics/health-emergencies/coronavirus-covid-19/news/news/2020/3/who-announcescovid-19-outbreak-a-pandemic.

4. Lu, H., C.W. Stratton, and Y.W. Tang, Outbreak of pneumonia of unknown etiology in Wuhan, China: The mystery and the miracle. J Med Virol, 2020. 92(4): p. 401-402.

5. Emma Farge, S.N., United States could become coronavirus epicenter: WHO, in GENEVA (Reuters). 2020

6. Coronavirus COVID-19 Global Cases by the Center for Systems Science and Engineering (CSSE) at Johns Hopkins University (JHU) 2020 [cited 2020 March 26]; Available from: https://gisanddata.maps.arcgis.com/apps/opsdashboard/index.html\#/bda7594740fd402994 23467b48e9ecf6.

7. https://www.who.int/dg/speeches/detail/who-director-general-s-opening-remarks-at-themedia-briefing-on-covid-19---3-march-2020, W.H.O.A.f.

8. Number of coronavirus (COVID-19) deaths in Europe since February 2020 (as of March 28, 2020), by country and date of report. 2020 [cited 2020 March 29]; Available from: https://www.statista.com/statistics/1102288/coronavirus-deaths-development-europe/.

9. Wang, L.-S., et al., A review of the 2019 Novel Coronavirus (COVID-19) based on current evidence. International Journal of Antimicrobial Agents, 2020: p. 105948.

10. Jeffrey K Aronson, R.E.F., Nicholas DeVito, Carl Heneghan, COVID-19 trials registered up to 8 March 2020-an analysis of 382 studies. 2020

11. McGrath, J., All the COVID-19 vaccines and treatments currently in clinical trials. 2020

12. FU Xiaoxia, L.L., TAN Xinghua, Clinical study on 37 case of COVID-19 treated with integrated traditional Chinese and Western Medicine. Traditional Chinese Drug Research and Clinical Pharmacology, (1003-9783,CN 44-1308/R).

13. Xue-mei, W.S.-z.W.H.-j.C.H.-m.Y.Y.B.F.-j.Z., Lianhua Qingwen capsule and interferon- $\alpha$ combined with lopinavir/ritonavir for the treatment of 30 COVID-19 patients. J Bengbu Med Coll, 2020. February 2020,Vol.45,No.2.

14. CHEN Jun, L.D., LIU Li, LIU Ping, XU Qingnian, XIA Lu, LING Yun, HUANG Dan, SONG Shuli, ZHANG Dandan, QIAN Zhiping, LI Tao, SHEN Yinzhong, LU Hongzhou, A pilot study of hydroxychloroquine in treatment of patients with common coronavirus disease-19 (COVID19). JOURNAL OF ZHEJIANG UNIVERSITY, 2020

15. Cao, B., et al., A Trial of Lopinavir-Ritonavir in Adults Hospitalized with Severe Covid-19. N Engl J Med, 2020.

16. Yuan, J., et al., The correlation between viral clearance and biochemical outcomes of 94 COVID-19 infected discharged patients. Inflamm Res, 2020.

17. Chen, Z., et al., Efficacy of hydroxychloroquine in patients with COVID-19: results of a randomized clinical trial. medRxiv, 2020: p. 2020.03.22.20040758.

18. Li, Y., et al., An exploratory randomized, controlled study on the efficacy and safety of lopinavir/ritonavir or arbidol treating adult patients hospitalized with mild/moderate COVID19 (ELACOI). medRxiv, 2020: p. 2020.03.19.20038984.

19. Chen, C., et al., Favipiravir versus Arbidol for COVID-19: A Randomized Clinical Trial. medRxiv, 2020: p. 2020.03.17.20037432.

20. SHI Jia, Y.Z., Ye Chen et Clinical observation on 49 cases of non-critical cornavirus disease 2019 in Shanghai treated by intergrated traditional Chinese and western medicine. Shanghai Journal of Traditional Chinese Medicine, 2020. 
21. Xia Wenchang, A.C., Zheng Chanjuan, 34 Cases of New Coronavirus Pneumonia treated with Integrated Traditional Chinese and Western Medicine. Journal of Traditional Chinese Medicine, 2020.

22. QU Xiang-kun, H.S.-I., MA Jing-he, WEI Guang-you, SONG Ke-yi, TANG Chao, GAO You-fang, LIANG Shao-qin, DU Wen-jie, Observation on clinical effect of Shufeng Jiedu Capsule combined with Arbidol Hydrochloride Capsule in treatment of COVID-19. Chinese Traditional and Herbal Drugs 2020.

23. CHEN Jun, L.y., XI xiu hong, The treatment effectiveness of Lopinaviltonivir and Abidol for Coronavirus disease. Chinese Journal of Infectious Diseases, 2020.

24. CHENG Dezhong, L.Y., Clinical Effectiveness and Case Analysis in 54 NCP Patients Treated with Lanhuaqingwen Granules. World Chinese Medicine, January . 2020, . . Vol.15,No.2.

25. Lu, R., W. Wang and X. Li., Clinical observation on 63 cases of suspected cases of new coronavirus pneumonia treated by Chinese medicine Lianhua Qingwen. Tradit. Chin. Med., 2020.

26. Yao, K., M. Liu, X. Li, J. Huang and H. Cai., Retrospective clinical analysis on treatment of novel coronavirus-infected pneumonia with traditional Chinese medicine Lianhua Qingwen. Chin. J. Exp. Tradit. Med. Formulae,, 2020

27. Medicine, N.A.o.T.C., Beijing's first confirmed case of new coronavirus pneumonia cured by Symptomatic and Chinese medicine treatment National Administration of Traditional Chinese Medicine, Beijing, 2020. 2020.

28. Administration, G.M.P., Notice on the clinical use of Tongjie Quwen Granules (formerly known as "pneumonia No. 1"). 2020.

29. Yu Simiao, W.Z., Qin Enqiang, Clinical characteristics 25 patients with novel coronavirus pneumonia. Chinese Journal of Integrated Traditional Chinese and Western Medicine, 2020.

30. XU Kaijin, C.H., SHEN Yihong et., Management of corona virus disease-19 (COVID-19): the Zhejiang experience. Journal of Zhejiang University(Medical Sciences), 2020.

31. Zhu Miao, L.Q., Gu Minghua et., Clinical diagnosis and intergrated treatment of traditional Chinese medicine and western medicine for confirmed patients with cornavirus disease 2019 in Yangzhou city of Jiangsu province Journal of Clinical Medicine in Practice, 2020.

32. GAO Ting, X.Y., HE Xiaopeng et, Epidemiological and clinical characteristics of 40 patients with coronavirus disease 2019 outside Hubei. Chinese Journal of Respiratory and Critical Care Medicine, 2020.

33. Weining, Z.X.Z.D.Z.J.e., Clinical characteristics of 463 patients with common and severe type coronavirus disease 2019. Shanghai Medical Journal, 2020.

34. LI Weijie, W.L., XU Yanjiao, GUO Jieru, ZHANG Chengliang, LIU Dong, LI Juan, Drug Utilization Evaluation on Antiviral Treatment in Patients with Severe Coronavirus Disease 2019: Lopinavir/ritonavir. Herald of Medicine, 2020.

35. Duan, K., et al., Effectiveness of convalescent plasma therapy in severe COVID-19 patients. Proc Natl Acad Sci U S A, 2020.

36. Deng, L., et al., Arbidol combined with $L P V / r$ versus $L P V / r$ alone against Corona Virus Disease 2019: A retrospective cohort study. J Infect, 2020.

37. Bian, H., et al., Meplazumab treats COVID-19 pneumonia: an open-labelled, concurrent controlled add-on clinical trial. medRxiv, 2020: p. 2020.03.21.20040691.

38. Ren, J.L., A.H. Zhang, and X.J. Wang, Traditional Chinese medicine for COVID-19 treatment. Pharmacol Res, 2020. 155: p. 104743.

39. National Health Commission \& State Administration of Traditional Chinese Medicine, Diagnosis and Treatment Protocol for COVID-19 Pneumonia. 2020.

40. Wang, M., et al., Remdesivir and chloroquine effectively inhibit the recently emerged novel coronavirus (2019-nCoV) in vitro. Cell Research, 2020. 30(3): p. 269-271. 
41. Gautret, P., et al., Hydroxychloroquine and azithromycin as a treatment of COVID-19: results of an open-label non-randomized clinical trial. International Journal of Antimicrobial Agents, 2020: p. 105949.

42. Molina, J.M., et al., No Evidence of Rapid Antiviral Clearance or Clinical Benefit with the Combination of Hydroxychloroquine and Azithromycin in Patients with Severe COVID-19 Infection, Med Mal Infect, 2020.

43. Raoult Didier, Available from: https://www.mediterranee-infection.com/wpcontent/uploads/2020/04/Abstract_Raoult_EarlyTrtCovid19_09042020_vD1v.pdf, 2020.

44. Province, H.C.o.G., Expert consensus on chloroquine phosphate for the treatment of novel coronavirus pneumonia. Chinese Journal of Tuberculosis and Respiratory Diseases, 2020. 43(3): p. 185-188.

45. PATTERSON, A.S., Here's why the WHO responded so differently to Zika and Ebola. 2016, Washington post. 


.

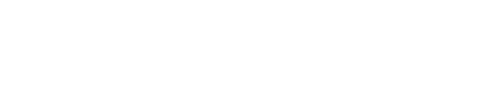

(2)

-

\author{
Table 1 Rationale for the use owis for coviD-19

\author{
Tables and figures
Table 1 Rationale for the use of WMs for COVID-19 \\ Tables and figures
Table 1 Rationale for the use of WMs for COVID-19
}

0

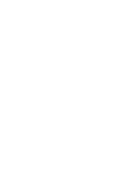

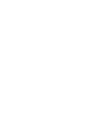

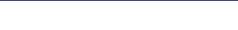

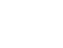

.

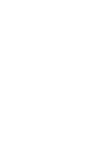

(n) 


\begin{tabular}{|c|c|c|c|}
\hline Drug name & Description & Mechanism of Action & Rationale for managing COVID-2019 \\
\hline \multicolumn{4}{|l|}{ Anti-virus agents } \\
\hline Lopinavir-ritonavir & HIV protease inhibitor & $\begin{array}{l}\text { Bind to the key enzyme for coronavirus replication and } \\
\text { suppress coronavirus activity }\end{array}$ & $\begin{array}{l}\text { In vitro, animal model and possible } \\
\text { clinical efficacy }\end{array}$ \\
\hline Favipiravir & $\begin{array}{l}\text { Broad spectrum inhibitor of RNA-dependent RNA polymerase, } \\
\text { typically used in treating influenza }\end{array}$ & Inhibit viral RNA synthesis & In vitro and possible clinical efficacy \\
\hline Azvudine & $\begin{array}{l}\text { Azidocytidine nucleoside analogue and HIV reverse } \\
\text { transcriptase inhibitor }\end{array}$ & Prevent virus from replicating & Possible clinical efficacy \\
\hline Danorevir Sodium + Ritonavir & Peptidomimetic inhibitor of the NS3/4A protease of HCV & $\begin{array}{l}\text { Structure similarity between chymotrypsin-like protease of } \\
\text { SARS-CoV- } 2 \text { shares and HCV proteases }\end{array}$ & Possible clinical efficacy \\
\hline Baloxavir Marboxil & Inhibitor of influenza virus cap-dependent endonuclease & Similarities between SARS-CoV-2 and H5N1 & Possible clinical efficacy \\
\hline ASC09-ritonavir & HIV protease inhibitor & $\begin{array}{l}\text { Structure similarity between chymotrypsin-like protease of } \\
\text { SARS-CoV-2 shares and HIV proteases }\end{array}$ & Possible clinical efficacy \\
\hline Darunavir & HIV protease inhibitor & $\begin{array}{l}\text { Structure similarity between chymotrypsin-like protease of } \\
\text { SARS-CoV- } 2 \text { shares and HIV proteases }\end{array}$ & Possible clinical efficacy \\
\hline $\begin{array}{l}\text { Emtritabine }+ \text { Tenofovir alafenamide } \\
\text { Fumarate }\end{array}$ & HIV reverse transcriptase inhibitor & Prevent virus from replicating & Possible clinical efficacy \\
\hline Triazavirin & $\begin{array}{l}\text { Broad spectrum non-nucleoside antiviral drug with efficacy } \\
\text { against influenza } A \text { and } B\end{array}$ & Similarities between SARS-CoV- 2 and H5N1 & Possible clinical efficacy \\
\hline Umifenovir & $\begin{array}{l}\text { Broad spectrum inhibitor of membrane haemagglutinin } \\
\text { fusion,typicaly in influenza viruses }\end{array}$ & Reduce the risk of bacterial pneumonia & Possible clinical efficacy \\
\hline \multicolumn{4}{|l|}{ Biologics } \\
\hline Interferon & $\begin{array}{l}\text { Activate cytoplasmic enzymes affecting viral messenger RNA } \\
\text { translation and protein synthesis }\end{array}$ & Crucial cytokines in immune system & Possible clinical efficacy \\
\hline $\begin{array}{l}\text { Enoxaparin and Nebulized Heparin- } \mathrm{N}- \\
\text { acetylcysteine }\end{array}$ & Anti-clotting agent, know as low molecular weight heparin & $\begin{array}{l}\text { Heparin as a potential attachment factor for the Spike Protein } \\
\text { of SARS-CoV-2 virus }\end{array}$ & In vitro and possible clinical efficacy \\
\hline Tocilizumab & IL-6 Receptor-Inhibiting Monoclonal Antibody & $\begin{array}{l}\text { Inhibit diverse physiological processes such as T-cell } \\
\text { activation, immunoglobulin secretion induction, hepatic } \\
\text { acute-phase protein synthesis initiation, and hematopoietic } \\
\text { precursor cell proliferation and differentiation stimulation }\end{array}$ & Possible clinical efficacy \\
\hline Adalimumab & Targeting TNF-alfa & $\begin{array}{l}\text { Used to treat rheumatoid arthritis, juvenile idiopathic } \\
\text { arthritis, ankylosing spondylitis, psoriatic arthritis, psoriasis, } \\
\text { hidradenitis suppurativa, Crohn's disease, ulcerative colitis, } \\
\text { and uveitis }\end{array}$ & Possible clinical efficacy \\
\hline Anti-programmed cell death-1 & Targeting receptors for PD-1 & Limit T cell activity during infection to reduce inflammation & Possible clinical efficacy \\
\hline Polyinosinic-Polycytidylic Acid & $\begin{array}{l}\text { Toll like receptor agonists } \\
\text { (TLR)3 }\end{array}$ & $\begin{array}{l}\text { Augment the production of IFN- } \alpha,-\beta \text {, and }-\gamma \text {, which } \\
\text { consequently inhibited CoV replication and compensated for } \\
\text { the inhibitory effectsof CoV on IFN signaling pathways }\end{array}$ & In vitro and possible clinical efficacy \\
\hline $\begin{array}{l}\text { Probiotics and intestinal flora } \\
\text { regulator }\end{array}$ & Interact with gut microbiome to reinforce our immune system & $\begin{array}{l}\text { Elevating immunogenicity by influencing seroconversion and } \\
\text { seroprotection rates }\end{array}$ & Possible clinical efficacy \\
\hline $\begin{array}{l}\text { Recombinant human granulocyte } \\
\text { colony-stimulating factor, rhG-CSF }\end{array}$ & $\begin{array}{l}\text { Directs the activation, proliferation, and differentiation of } \\
\text { myeloid-derived cells and causes maturation of antigen- } \\
\text { presenting cells, thus affecting adaptive immune responses }\end{array}$ & $\begin{array}{l}\text { 3C-like protease of SARS-CoV-1 reduces expression of } \\
\text { granulocyte-macrophage colony-stimulating factor (GM-CSF) } \\
\text { in transfected cells }\end{array}$ & In vitro and possible clinical efficacy \\
\hline Recombinant Human Interleukin-2 & Multiple anti-inflammatory actions & Crucial cytokines in immune system & Possible clinical efficacy \\
\hline $\begin{array}{l}\text { Recombinant viral macrophage } \\
\text { inflammatory protein }\end{array}$ & Advanced Therapy Medicinal Products & Not known & Possible clinical efficacy \\
\hline
\end{tabular}


Thymosin

Ulinastatin

Camrelizumab

Maplazumab

Mycobacterium vaccae injection

Antiparasitic agents

Chloroquine and Hydroxychloroquine

Suramin sodium

Cell-based therapy

Mesenchymal stem cells

Plasma therapy

Convalescent plasma

Anti-inflammatory agents
Methylprednisolone and

Corticosteroid

Jakotinib hydrochloride

Leflunomide

Tranilast

\section{Others}

Pirfenidone

Hydrogen Peroxide gargle

Lipoic acid injection

Bismuth potassium citrate

Carrimycin

A group of polypeptides, initially isolated from the thymus

Protease inhibitor to inhibit the activity of polymorphonuclear leukocyte elastase

Anti-PD-1 checkpoint inhibitor and used in China to treat Hodgkin's lymphoma and nasopharyngeal carcinoma

Targeting CD147

The same genus as Mycobacterium tuberculosis

Antimalarial actions and some efficacy in HIV-AIDS

Used to treat first-stage African trypanosomiasis and onchocerciasis

Adult stem cells and can be taken from either humans or animals

Contains nonspecific antibodies

Anti-inflammatory actions

Chinese literature only and presumed inhibitor of Janusassociated kinases

Immunosuppressant and inhibitor of dihydro-orotate

dehydrogenase and tyrosine kinases

Anti-allergic and inhibitor of NLRP3 in the inflammasome pathway

Reduces fibroblast proliferation and production of fibrosisassociated proteins and cytokines

Non-specific supposed antiviral action in the throat

Vitamin-like antioxidant

Inhibits growth of Helicobacter pylori

Polyether antibiotic and active against Gram-positive bacteria, mycoplasma, fungi and yeasts

HIV: The human immunodeficiency viruses; RNA: Ribonucleic acid; HCV: Hepatitis C: SARS-CoV-2: severe acute respiratory syndrome coronavirus 2; H5N1: A bird-adapted strain of H5N1; IL-6: Interleukin-6; TNF: Tumor necrosis factor; PD-1: programmed cell death protein 1; GM-CSF: granulocyte-macrophage colony-stimulating factor; INF: Interferons; ACE: Angiotensin-converting enzyme; HIV/AIDS: Human immunodeficiency virus

infection and acquired immune deficiency syndrome
Involved in T-cell differentiation and used in cancer treatment Possible clinical efficacy with little evidence of benefit

Modulating inflammatory reaction

Possible clinical efficacy

Being compared to thymosin for the prevention of sepsis in COVID-19 patients

Not known

Possible clinical efficacy

Possible clinical efficacy Possible clinical efficacy

Inhibit glycosylation of viral ACE-2 or inhibition of quinone reductase 2 , reducing synthesis of viral sialic acid

Not known

In vitro and possible clinical efficacy

Possible clinical efficacy

Efficacy of treating lung damage caused by radiation fo cancer treatment

Block viral Fc receptor activation by boosting endogenous neutralizing antibodies and preventing antibody-dependent enhancement of infection

Experience with corticosteroids in other infectious diseases has not been uniformly beneficial and in SARS corticosteroids may worsen the disease

Not known

Possible clinical efficacy

Causes degradation of intracellular transcription factors and Possible clinical efficacy used to treat rheumatoid arthritis and psoriatic arthritis Modulating inflammatory reaction

Possible clinical efficacy

\section{Not known}

Possible clinical efficacy

Possible clinical efficacy

Possible clinical efficacy

In vitro and possible clinical efficacy

Possible clinical efficacy 
Table 2 Clinical trials of antivirus agents for the treatment of COVID-19 in China from the Chinese Clinical Trial Registry

\begin{tabular}{|c|c|c|c|c|c|c|c|}
\hline Trial ID & $\begin{array}{l}\text { Planned date } \\
\text { of enrollment }\end{array}$ & $\begin{array}{l}\text { Recruitment } \\
\text { status }\end{array}$ & $\begin{array}{l}\text { Study } \\
\text { design }\end{array}$ & $\begin{array}{l}\text { Population (number of } \\
\text { patients) }\end{array}$ & Intervention (dosing, if available) & $\begin{array}{l}\text { Control (dosing, if } \\
\text { available) }\end{array}$ & Primary outcome \\
\hline ChiCTR2000029548 & $04 / 02 / 2020$ & Pending & Non-RCT & $\begin{array}{l}\text { COVID-19 pneumonia } \\
(n=30)\end{array}$ & $\begin{array}{l}\text { Group 1: Baloxavir Marboxil ( } 80 \mathrm{mg} \text { on } \\
\text { day1,80mg on day4, } 80 \mathrm{mg} \text { on day7 as } \\
\text { necessary); } \\
\text { Group 2: Favipiravir (First dose: } \\
1600 \mathrm{mg} \text {; then } 600 \mathrm{mg} \text {, tid for no more } \\
\text { than } 14 \text { days) } \\
\text { Group 3: Lopinavir-ritonavir } \\
\text { (200mg/50 mg, bid for } 14 \text { days) }\end{array}$ & NA & $\begin{array}{l}\text { Time to nucleic acid negativity; Time to clinical } \\
\text { improvement }\end{array}$ \\
\hline ChiCTR2000029541 & $10 / 02 / 2020$ & Pending & RCT & $\begin{array}{l}\text { COVID-19 pneumonia } \\
(n=120)\end{array}$ & $\begin{array}{l}\text { Group 1: Darunavir-cobicistat } \\
\text { ( } 800 \mathrm{mg} / 150 \mathrm{mg}, \text { qd) + Thymosin } \alpha 1 \\
\text { (1.6 mg, sc, qod) + Standard of care; } \\
\text { Group 2: Lopinavir-ritonavir } \\
(400 \mathrm{mg} / 100 \mathrm{mg}, \text { bid) + Thymosin } \alpha 1 \\
(1.6 \mathrm{mg}+\mathrm{sc}, \mathrm{qod})+\text { Standard of care }\end{array}$ & $\begin{array}{l}\text { Thymosin a1 (1.6 } \\
\mathrm{mg} \text {, sc, qd) + } \\
\text { Standard of care }\end{array}$ & Time to nucleic acid negativity \\
\hline ChiCTR2000030187 & $25 / 02 / 2020$ & Recruiting & RCT & $\begin{array}{l}\text { COVID-19 pneumonia } \\
(n=60)\end{array}$ & Lopinavir-ritonavir & Standard of care & Mortality; Rate of nucleic acid negativity \\
\hline ChiCTR2000029308 & $10 / 01 / 2020$ & Recruiting & RCT & $\begin{array}{l}\text { COVID-19 pneumonia } \\
(n=160)\end{array}$ & $\begin{array}{l}\text { Lopinavir-ritonavir }(400 \mathrm{mg} / 100 \mathrm{mg} \text {, } \\
\text { bid) }\end{array}$ & Standard of care & Time to clinical improvement \\
\hline ChiCTR2000029539 & $04 / 02 / 2020$ & Recruiting & RCT & $\begin{array}{l}\text { COVID-19 pneumonia } \\
(n=328)\end{array}$ & $\begin{array}{l}\text { Lopinavir-ritonavir+ Standard of care } \\
\text { Standard of care }\end{array}$ & Standard of care & Rate of composite adverse outcome \\
\hline ChiCTR2000029996 & $20 / 02 / 2020$ & Recruiting & RCT & $\begin{array}{l}\text { Moderate COVID-19 } \\
\text { pneumonia }(n=60)\end{array}$ & $\begin{array}{l}\text { Group1: Farpiravir (First dose } \\
\text { 1600mg; then } 200 \mathrm{mg} \text { bid for } 9 \text { days); } \\
\text { Group 2: Farpiravir (First dose } \\
\text { 1800mg; then } 200 \mathrm{mg} \text { bid for } 9 \text { days); } \\
\text { Group 3: Farpiravir (First dose } \\
2400 \mathrm{mg} \text {; then } 200 \mathrm{mg} \text { bid for } 9 \text { days) }\end{array}$ & NA & Time to clinical recovery \\
\hline ChiCTR2000029544 & $04 / 02 / 2020$ & Pending & RCT & $\begin{array}{l}\text { COVID-19 pneumonia } \\
(n=30)\end{array}$ & $\begin{array}{l}\text { Group 1: Baloxavir Marboxi + } \\
\text { Standard of care; } \\
\text { Group 2: Fabiravir + Standard of care }\end{array}$ & Standard of care & $\begin{array}{l}\text { Time to and rate of nucleic acid negativity; Time to } \\
\text { clinical improvement }\end{array}$ \\
\hline ChiCTR2000030041 & $25 / 02 / 2020$ & Pending & Non-RCT & $\begin{array}{l}\text { Moderate and severe } \\
\text { COVID-19 pneumonia } \\
(n=40)\end{array}$ & Azivudine & NA & Rate of nucleic acid negative \\
\hline ChiCTR2000029853 & $16 / 02 / 2020$ & Recruiting & RCT & $\begin{array}{l}\text { COVID-19 pneumonia } \\
(n=20)\end{array}$ & Azivudine (5 tablets, qd) & $\begin{array}{l}\text { Standard } \\
\text { treatment }\end{array}$ & $\begin{array}{l}\text { Time to clinical recovery; Time to and rate of } \\
\text { nucleic acid negativity; Blood routine test; Rate of } \\
\text { progression; Days of hospitalization; Mortality }\end{array}$ \\
\hline ChiCTR2000030487 & 04/03/2020 & Recruiting & Non-RCT & $\begin{array}{l}\text { Moderate and severe } \\
\text { COVID-19 pneumonia } \\
(n=10)\end{array}$ & $\begin{array}{l}\text { Azivudine ( } 10 \mathrm{mg} \text {, qd on the first day; } \\
\text { then } 5 \mathrm{mg}, \mathrm{qd})+ \text { Standard of care }\end{array}$ & NA & Time to and rate of nucleic acid negativity \\
\hline ChiCTR2000030424 & $02 / 03 / 2020$ & Pending & Non-RCT & $\begin{array}{l}\text { Moderate and severe } \\
\text { COVID-19 pneumonia } \\
(n=30)\end{array}$ & $\begin{array}{l}\text { Azivudine ( } 10 \mathrm{mg} \text {, qd on the first day; } \\
\text { then } 5 \mathrm{mg}, \mathrm{qd})+ \text { Standard of care }\end{array}$ & NA & Time to and rate of nucleic acid negativity \\
\hline
\end{tabular}




\begin{tabular}{|c|c|c|c|c|c|c|c|}
\hline Trial ID & $\begin{array}{l}\text { Planned date } \\
\text { of enrollment }\end{array}$ & $\begin{array}{l}\text { Recruitment } \\
\text { status }\end{array}$ & $\begin{array}{l}\text { Study } \\
\text { design }\end{array}$ & $\begin{array}{l}\text { Population (number of } \\
\text { patients) }\end{array}$ & Intervention (dosing, if available) & $\begin{array}{l}\text { Control (dosing, if } \\
\text { available) }\end{array}$ & Primary outcome \\
\hline ChiCTR2000030000 & $16 / 02 / 2020$ & Recruiting & Non-RCT & $\begin{array}{l}\text { COVID-19 pneumonia } \\
(n=40)\end{array}$ & $\begin{array}{l}\text { Group 1: Danoprevir Sodium + } \\
\text { Ritonavir } \\
\text { Group 2: Pegasys injection } \\
\text { Group 3: Novaferon } \\
\text { Group 4: Lopinavir-ritonavir }\end{array}$ & $\begin{array}{l}\text { TCM + Spray } \\
\text { inhalation }\end{array}$ & Rate of composite adverse outcomes \\
\hline ChiCTR2000030259 & $22 / 02 / 2020$ & Recruiting & RCT & $\begin{array}{l}\text { Mild and Moderate } \\
\text { COVID-19 pneumonia } \\
(n=60)\end{array}$ & Danoprevir Sodium + Ritonavir & Standard of care & Rate of composite adverse outcomes \\
\hline ChiCTR2000030472 & $25 / 02 / 2020$ & Recruiting & Non-RCT & $\begin{array}{l}\text { COVID-19 pneumonia } \\
(n=20)\end{array}$ & $\begin{array}{l}\text { Danoprevir Sodium + Ritonavir + } \\
\text { Standard of care }\end{array}$ & Standard of care & Rate of composite adverse outcomes \\
\hline ChiCTR2000030113 & $22 / 02 / 2020$ & Recruiting & RCT & $\begin{array}{l}\text { COVID-19 pneumonia } \\
\text { with poorly responsive } \\
\text { Lopinavir/ritonavir } \\
(\mathrm{n}=30)\end{array}$ & Favipiravir & Lopinavir-ritonavir & Blood routine tests, Chest CT \\
\hline ChiCTR2000029603 & $06 / 02 / 2020$ & Recruiting & RCT & $\begin{array}{l}\text { COVID-19 pneumonia } \\
(n=160)\end{array}$ & ASC09-ritonavir+ Standard of care & $\begin{array}{l}\text { Lopinavir-ritonavir } \\
+ \text { Standard of care }\end{array}$ & Rate of composite adverse outcomes \\
\hline ChiCTR2000029468 & $01 / 02 / 2020$ & Pending & Non-RCT & $\begin{array}{l}\text { COVID-19 pneumonia } \\
(n=120)\end{array}$ & $\begin{array}{l}\text { Emtritabine + Lopinavir-ritonavir + } \\
\text { Tenofovir alafenamide Fumarate }\end{array}$ & Lopinavir-ritonavir & Survival rate \\
\hline ChiCTR2000030001 & $15 / 02 / 2020$ & Recruiting & RCT & $\begin{array}{l}\text { COVID-19 pneumonia } \\
(n=240)\end{array}$ & Triazavirin + Standard of care & Standard of care & Time to clinical recovery \\
\hline ChiCTR2000029621 & $07 / 02 / 2020$ & Recruiting & RCT & $\begin{array}{l}\text { COVID-19 pneumonia } \\
(n=380)\end{array}$ & Umifenovir + Standard of care & Standard of care & Rate of nucleic acid negativity \\
\hline ChiCTR2000030939 & $16 / 03 / 2020$ & Recruiting & Non-RCT & $\begin{array}{l}\text { COVID-19 pneumonia } \\
(n=10)\end{array}$ & LL-37 antiviral peptide & NA & Time to and rate of nucleic acid negativity \\
\hline
\end{tabular}

The standard of care followed the guidance of the "Diagnosis and Treatment Protocol for COVID-19 Pneumonia" published by the Chinese National Health Commission [39].

Nucleic acid negativity is defined by reverse transcription polymerase chain reaction (RT-PCR)

Rate of composite adverse outcomes is defined as SpO2<=93\% without oxygen supplementation, or PaO2/FiO2 $<=300 \mathrm{mmHg}$, or respiratory rate (RR) $<=30$ breaths per minute

Time to clinical recovery is defined as the normal body temperature (underarm temperature $<=36.9$ degrees $C$ ) and cough relief (evaluated by the cough symptom score scale) in the duration of at least 72 hours from the start of study treatment

RCT: Randomized clinical trial; COVID-19: Coronavirus Disease 2019; NA: Not available; qd: Once a day; bid: twice daily; tid: three times a day; qod: every other day; sc: subcutaneous; CT: computed tomography 
Table 3 Clinical trials of biologics for the treatment of COVID-19 in China from the Chinese Clinical Trial Registry

\begin{tabular}{|c|c|c|c|c|c|c|c|}
\hline Trial ID & $\begin{array}{l}\text { Planned date of } \\
\text { enrollment }\end{array}$ & $\begin{array}{l}\text { Recruitment } \\
\text { status }\end{array}$ & $\begin{array}{l}\text { Study } \\
\text { design }\end{array}$ & $\begin{array}{l}\text { Population } \\
\text { (number of } \\
\text { patients) }\end{array}$ & $\begin{array}{l}\text { Intervention (dosing, if } \\
\text { available) }\end{array}$ & $\begin{array}{l}\text { Control (dosing, if } \\
\text { available) }\end{array}$ & Primary outcome \\
\hline ChiCTR2000029765 & $10 / 02 / 2020$ & Recruiting & RCT & $\begin{array}{l}\text { Moderate and } \\
\text { severe COVID- } \\
19 \text { pneumonia } \\
(n=188)\end{array}$ & $\begin{array}{l}\text { Tocilizumab + Standard of } \\
\text { care }\end{array}$ & Standard of care & Clinical cure rate \\
\hline ChiCTR2000030196 & $20 / 02 / 2020$ & Pending & $\begin{array}{l}\text { Non- } \\
\text { RCT }\end{array}$ & $\begin{array}{l}\text { Moderate and } \\
\text { severe COVID- } \\
19 \text { pneumonia } \\
(n=60)\end{array}$ & $\begin{array}{l}\text { Tocilizumab }+ \text { Standard of } \\
\text { care }\end{array}$ & NA & The relive of cytokine release syndrome \\
\hline ChiCTR2000030701 & $10 / 03 / 2020$ & Pending & RCT & $\begin{array}{l}\text { Mild and } \\
\text { Moderate } \\
\text { COVID-19 } \\
\text { pneumonia } \\
(\mathrm{n}=60)\end{array}$ & $\begin{array}{l}\text { Enoxaparin Sodium }+ \\
\text { Standard of care }\end{array}$ & Standard of care & Time to Virus Eradication \\
\hline ChiCTR2000030700 & 09/03/2020 & Pending & RCT & $\begin{array}{l}\text { Mild and } \\
\text { Moderate } \\
\text { COVID-19 } \\
\text { pneumonia } \\
(\mathrm{n}=60)\end{array}$ & $\begin{array}{l}\text { Enoxaparin Sodium }+ \\
\text { Standard of care }\end{array}$ & Standard of care & Time to Virus Eradication \\
\hline ChiCTR2000030328 & $02 / 03 / 2020$ & Pending & $\begin{array}{l}\text { Non- } \\
\text { RCT }\end{array}$ & $\begin{array}{l}\text { COVID-19 } \\
\text { pneumonia } \\
(\mathrm{n}=60)\end{array}$ & $\begin{array}{l}\text { Nebulized Heparin- } \mathrm{N} \text { - } \\
\text { acetylcysteine }\end{array}$ & Placebo & $\begin{array}{l}\text { Chest CT; Days of hospitalization; Rate of } \\
\text { nucleic acid negativity }\end{array}$ \\
\hline ChiCTR2000030089 & $28 / 02 / 2020$ & Pending & RCT & $\begin{array}{l}\text { Several and } \\
\text { critical COVID- } \\
19 \text { pneumonia } \\
(n=60)\end{array}$ & $\begin{array}{l}\text { Adalimumab + Standard of } \\
\text { care }\end{array}$ & Standard of care & Time to clinical improvement \\
\hline ChiCTR2000030580 & $01 / 02 / 2020$ & Recruiting & RCT & $\begin{array}{l}\text { Severe COVID- } \\
19 \text { pneumonia } \\
(n=60)\end{array}$ & $\begin{array}{l}\text { Adalimumab + Tocilizumab + } \\
\text { Standard of care }\end{array}$ & Standard of care & $\begin{array}{l}\text { Chest CT; Time to nucleic acid negativity } \\
\text { Immunosuppressive biomarkers test }\end{array}$ \\
\hline ChiCTR2000030028 & $24 / 02 / 2020$ & Pending & RCT & $\begin{array}{l}\text { Several and } \\
\text { critical COVID- } \\
19 \text { pneumonia } \\
(n=40)\end{array}$ & $\begin{array}{l}\text { Anti-programmed cell death- } \\
1 \text { monoclonal antibody }+ \\
\text { Standard of care }\end{array}$ & Standard of care & Immunosuppressive biomarkers \\
\hline ChiCTR2000029776 & $11 / 02 / 2020$ & Recruiting & RCT & $\begin{array}{l}\text { COVID-19 } \\
\text { pneumonia } \\
(\mathrm{n}=40)\end{array}$ & $\begin{array}{l}\text { Polyinosinic-Polycytidylic Acid } \\
\text { Injection + Standard of care }\end{array}$ & Standard of care & Time to clinical recovery \\
\hline ChiCTR2000029974 & $09 / 02 / 2020$ & Recruiting & RCT & $\begin{array}{l}\text { COVID-19 } \\
\text { pneumonia } \\
(\mathrm{n}=300)\end{array}$ & Probiotics + Standard of care & Standard of care & Time to clinical recovery \\
\hline
\end{tabular}

.

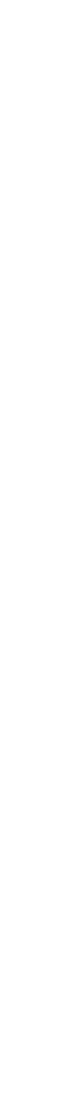




\begin{tabular}{|c|c|c|c|c|c|c|c|}
\hline Trial ID & $\begin{array}{l}\text { Planned date of } \\
\text { enrollment }\end{array}$ & $\begin{array}{l}\text { Recruitment } \\
\text { status }\end{array}$ & $\begin{array}{l}\text { Study } \\
\text { design }\end{array}$ & $\begin{array}{l}\text { Population } \\
\text { (number of } \\
\text { patients) }\end{array}$ & $\begin{array}{l}\text { Intervention (dosing, if } \\
\text { available) }\end{array}$ & $\begin{array}{l}\text { Control (dosing, if } \\
\text { available) }\end{array}$ & Primary outcome \\
\hline ChiCTR2000030007 & $03 / 02 / 2020$ & Pending & RCT & $\begin{array}{l}\text { Mild, moderate, } \\
\text { and severe } \\
\text { COVID-19 } \\
\text { pneumonia } \\
(\mathrm{n}=200)\end{array}$ & $\begin{array}{l}\text { Recombinant human } \\
\text { granulocyte colony- } \\
\text { stimulating factor }(5 \mu \mathrm{g} / \mathrm{kg})+ \\
\text { Standard of care }\end{array}$ & Standard of care & $\begin{array}{l}\text { Clinical symptoms; Blood routine test; Viral } \\
\text { load; Immunosuppressive biomarkers test; } \\
\text { Chest CT }\end{array}$ \\
\hline ChiCTR2000030480 & $03 / 03 / 2020$ & Recruiting & RCT & $\begin{array}{l}\text { COVID-19 } \\
\text { pneumonia } \\
(\mathrm{n}=328)\end{array}$ & $\begin{array}{l}\text { Interferon } \alpha 1 \beta \text { (10UG bid for } \\
10 \text { days) + Standard of care }\end{array}$ & Standard of care & Rate of composite adverse outcomes \\
\hline ChiCTR2000029989 & $20 / 02 / 2020$ & Pending & RCT & $\begin{array}{l}\text { COVID-19 } \\
\text { pneumonia } \\
(\mathrm{n}=300)\end{array}$ & Interferon $\alpha 1 \beta$ Eye Drops & Placebo drop & Time to Clinical recovery \\
\hline ChiCTR2000030167 & $02 / 03 / 2020$ & Pending & RCT & $\begin{array}{l}\text { Mild and } \\
\text { Moderate } \\
\text { COVID-19 } \\
\text { pneumonia } \\
(\mathrm{n}=80)\end{array}$ & $\begin{array}{l}\text { Recombinant Human } \\
\text { Interleukin-2 ( } 1 \text { million IU per } \\
\text { time, qod for } 2 \text { weeks) + } \\
\text { Standard of care }\end{array}$ & Standard of care & $\begin{array}{l}\text { Immunosuppressive biomarkers test; } \\
\text { Mortality; Time to clinical recovery }\end{array}$ \\
\hline ChiCTR2000029636 & $09 / 02 / 2020$ & Recruiting & $\begin{array}{l}\text { Non- } \\
\text { RCT }\end{array}$ & $\begin{array}{l}\text { COVID-19 } \\
\text { pneumonia } \\
(\mathrm{n}=40)\end{array}$ & $\begin{array}{l}\text { Recombinant viral } \\
\text { macrophage inflammatory } \\
\text { protein + Standard of care }\end{array}$ & NA & Time to nucleic acid negativity \\
\hline ChiCTR2000029849 & $01 / 02 / 2020$ & Recruiting & RCT & $\begin{array}{l}\text { COVID-19 } \\
\text { pneumonia } \\
(\mathrm{n}=60)\end{array}$ & $\begin{array}{l}\text { Regulating intestinal flora }+ \\
\text { Standard of care }\end{array}$ & Standard of care & Days of hospitalization; Mortality \\
\hline ChiCTR2000029806 & $12 / 02 / 2020$ & Recruiting & RCT & $\begin{array}{l}\text { Severe COVID- } \\
19 \text { pneumonia } \\
(\mathrm{n}=120)\end{array}$ & $\begin{array}{l}\text { Group 1: Thymosin (1.6 mg sc } \\
\text { qd for } 5 \text { days) + Standard of } \\
\text { care } \\
\text { Group 2: Camrelizumab ( } 200 \\
\mathrm{mg} \text { single dose) + Standard of } \\
\text { care }\end{array}$ & Standard of care & $\begin{array}{l}\text { Proportion of patients with a lung injury score } \\
\text { reduction of 1-point or more } 7 \text { days after } \\
\text { randomization }\end{array}$ \\
\hline ChiCTR2000030779 & $16 / 03 / 2020$ & Recruiting & RCT & $\begin{array}{l}\text { Severe COVID- } \\
19 \text { pneumonia } \\
(n=100)\end{array}$ & Ulinastatin + Standard of care & Standard of care & Blood gas; Sequential organ failure assessment \\
\hline ChiCTR2000030016 & $04 / 02 / 2020$ & Recruiting & RCT & $\begin{array}{l}\text { COVID-19 } \\
\text { pneumonia } \\
(n=30)\end{array}$ & $\begin{array}{l}\text { Mycobacterium vaccae } \\
\text { injection + Standard of care }\end{array}$ & $\begin{array}{l}\text { Placebo }+ \\
\text { Standard of care }\end{array}$ & $\begin{array}{l}\text { Time to nucleic acid negativity Mortality; } \\
\text { Adverse events; Time to clinical improvement }\end{array}$ \\
\hline ChiCTR2000029638 & $03 / 02 / 2020$ & Recruiting & RCT & $\begin{array}{l}\text { COVID-19 } \\
\text { pneumonia } \\
(\mathrm{n}=100)\end{array}$ & $\begin{array}{l}\text { Nebulization of recombinant } \\
\text { super-compound interferon }\end{array}$ & $\begin{array}{l}\text { Nebulization of } \\
\text { interferon } \alpha \mathrm{lb}\end{array}$ & $\begin{array}{l}\text { Clinical symptoms; Immunosuppressive } \\
\text { biomarkers test; Chest CT }\end{array}$ \\
\hline
\end{tabular}

\section{(1)}

(⿸丆口

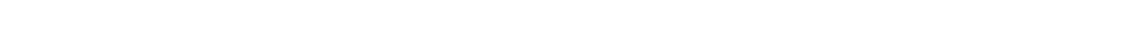

6

(2.

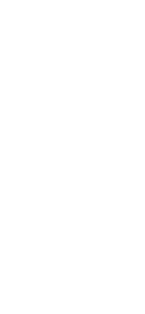

(1)

列


The standard of care followed the guidance of the "Diagnosis and Treatment Protocol for COVID-19 Pneumonia" published by the Chinese National Health Commission [39]. Nucleic acid negativity is defined by reverse transcription polymerase chain reaction (RT-PCR)

Rate of composite adverse outcomes is defined as $\mathrm{SpO2}<=93 \%$ without oxygen supplementation, or PaO2/FiO2 $<=300 \mathrm{mmHg}$, or respiratory rate (RR) $<=30$ breaths per minute

Time to clinical recovery is defined as the normal body temperature (underarm temperature $<=36.9$ degrees $\mathrm{C}$ ) and cough relief (evaluated by the cough symptom score scale) in the duration of at least 72 hours from

the start of study treatment

RCT: Randomized clinical trial; COVID-19: Coronavirus Disease 2019; NA: Not available; qd: Once a day; bid: twice daily; tid: three times a day; qod: every other day; sc: subcutaneous; CT: computed tomography

RCT:Randomized clinicaltrialic 
Table 4 Clinical trials of antiparasitic agents for the treatment of COVID-19 in China from the Chinese Clinical Trial Registry

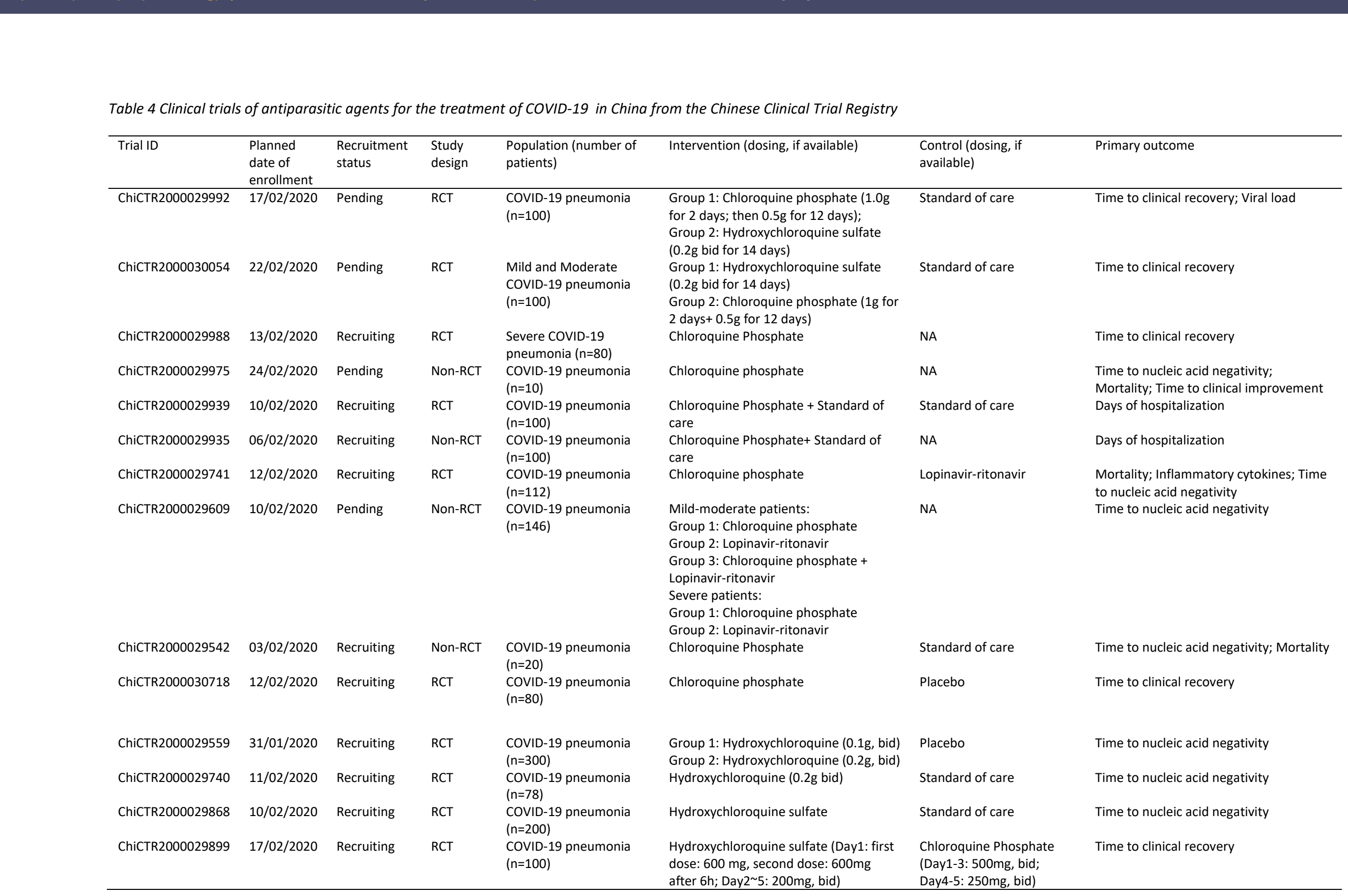




\begin{tabular}{|c|c|c|c|c|c|c|c|}
\hline Trial ID & $\begin{array}{l}\text { Planned } \\
\text { date of } \\
\text { enrollment }\end{array}$ & $\begin{array}{l}\text { Recruitment } \\
\text { status }\end{array}$ & $\begin{array}{l}\text { Study } \\
\text { design }\end{array}$ & $\begin{array}{l}\text { Population (number of } \\
\text { patients) }\end{array}$ & Intervention (dosing, if available) & $\begin{array}{l}\text { Control (dosing, if } \\
\text { available) }\end{array}$ & Primary outcome \\
\hline ChiCTR2000029898 & $17 / 02 / 2020$ & Recruiting & RCT & $\begin{array}{l}\text { Severe COVID-19 } \\
\text { pneumonia }(n=100)\end{array}$ & $\begin{array}{l}\text { Hydroxychloroquine sulfate (Day1: first } \\
\text { dose: } 600 \mathrm{mg} \text {, second dose: } 600 \mathrm{mg} \\
\text { after } 6 \mathrm{~h} \text {; Day2-5: } 200 \mathrm{mg} \text {, bid) }\end{array}$ & $\begin{array}{l}\text { Chloroquine Phosphate } \\
\text { (Day1-3: } 500 \mathrm{mg} \text {, bid; } \\
\text { Day4-5: } 250 \mathrm{mg} \text {, bid) }\end{array}$ & Time to clinical improvement \\
\hline ChiCTR2000030029 & $20 / 02 / 2020$ & Pending & Non-RCT & $\begin{array}{l}\text { COVID-19 pneumonia } \\
\text { with poorly response } \\
(n=20)\end{array}$ & Suramin sodium & NA & Clinical cure rate; Mortality \\
\hline
\end{tabular}

The standard of care followed the guidance of the "Diagnosis and Treatment Protocol for COVID-19 Pneumonia" published by the Chinese National Health Commission [39].

Nucleic acid negativity is defined by reverse transcription polymerase chain reaction (RT-PCR)

Rate of composite adverse outcomes is defined as SpO2<=93\% without oxygen supplementation, or PaO2/FiO2 $<=300 \mathrm{mmHg}$, or respiratory rate (RR) $<=30$ breaths per minute

Time to clinical recovery is defined as the normal body temperature (underarm temperature $<=36.9$ degrees $C$ ) and cough relief (evaluated by the cough symptom score scale) in the duration of at least 72 hours from the start of study treatment

RCT: Randomized clinical trial; COVID-19: Coronavirus Disease 2019; NA: Not available; bid: twice daily \\ doi:10.20944/preprints202004.0279.v1}


Table 5 Clinical trials of cell-based therapy for the treatment of COVID-19 in China from the Chinese Clinical Trial Registry

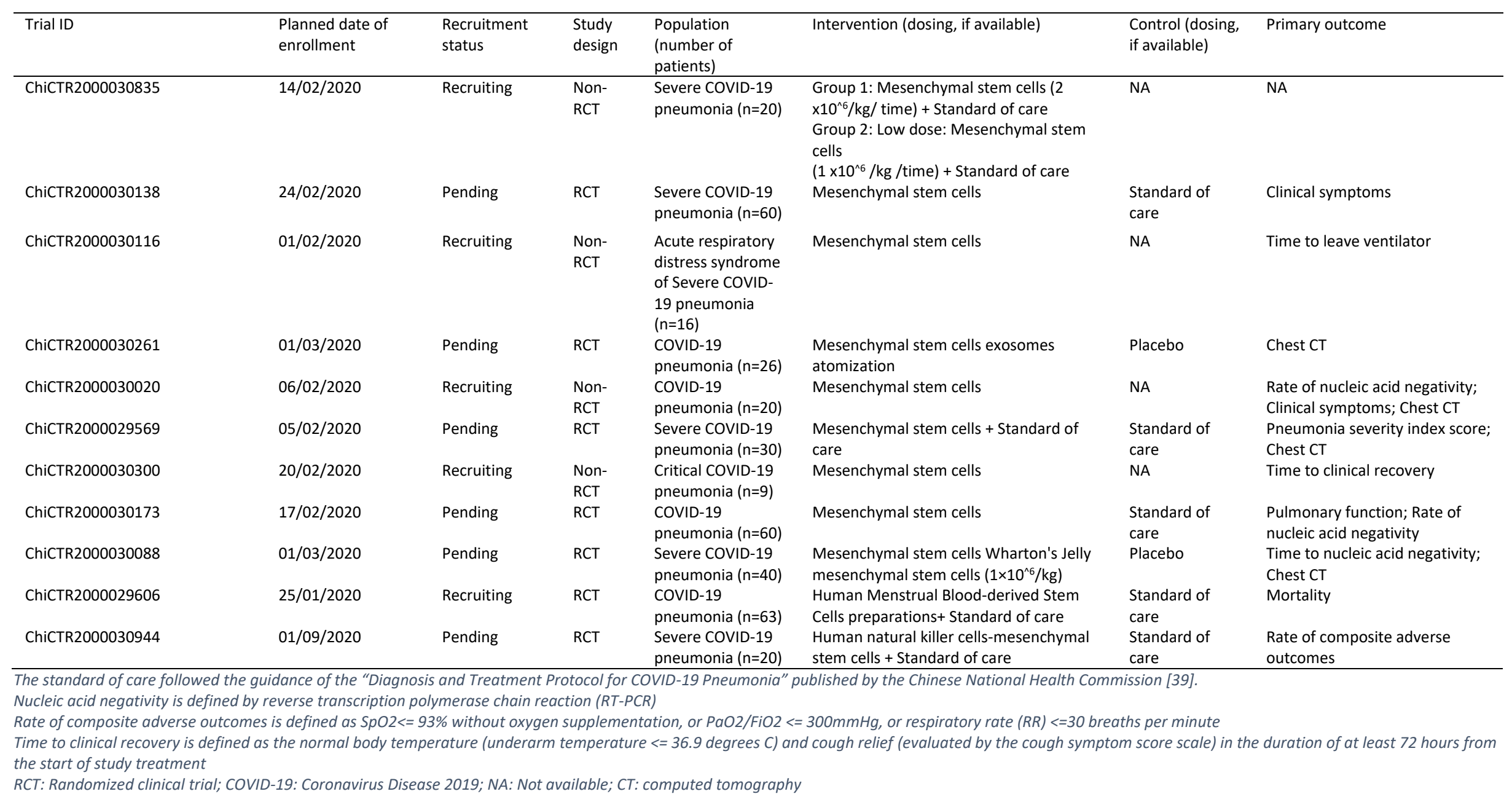


Table 6 Clinical trials of plasma therapy for the treatment of COVID-19 in China from the Chinese Clinical Trial Registry

\begin{tabular}{|c|c|c|c|c|c|c|c|}
\hline Trial ID & $\begin{array}{l}\text { Planned date } \\
\text { of enrollment }\end{array}$ & $\begin{array}{l}\text { Recruitment } \\
\text { status }\end{array}$ & $\begin{array}{l}\text { Study } \\
\text { design }\end{array}$ & $\begin{array}{l}\text { Population (number of } \\
\text { patients) }\end{array}$ & Intervention (dosing, if available) & $\begin{array}{l}\text { Control (dosing, if } \\
\text { available) }\end{array}$ & Primary outcome \\
\hline ChiCTR2000030039 & $31 / 05 / 2020$ & Recruiting & Non-RCT & $\begin{array}{l}\text { Moderate, severe and critical } \\
\text { COVID-19 pneumonia }(n=90)\end{array}$ & $\begin{array}{l}\text { Convalescent plasma }(200-500 \mathrm{ml} \text {, } \\
\text { two infusions) + Standard of care }\end{array}$ & Standard of care & SARS-CoV-2 DNA; SARS-CoV-2 antibody levels \\
\hline ChiCTR2000030702 & $15 / 02 / 2020$ & Recruiting & RCT & $\begin{array}{l}\text { Moderate COVID-19 } \\
\text { pneumonia }(n=50)\end{array}$ & $\begin{array}{l}\text { Convalescent plasma }+ \text { Standard } \\
\text { of care }\end{array}$ & Standard of care & Time to clinical recovery \\
\hline ChiCTR2000030627 & $01 / 02 / 2020$ & Recruiting & RCT & $\begin{array}{l}\text { Severe COVID-19 pneumonia } \\
(n=30)\end{array}$ & $\begin{array}{l}\text { Convalescent plasma }+ \text { Standard } \\
\text { of care }\end{array}$ & Standard of care & Temperature; Virus nucleic acid detection \\
\hline ChiCTR2000030179 & $24 / 02 / 2020$ & Recruiting & RCT & $\begin{array}{l}\text { Severe COVID-19 pneumonia } \\
(n=100)\end{array}$ & $\begin{array}{l}\text { Convalescent plasma therapy }+ \\
\text { Standard of care }\end{array}$ & Standard of care & Clinical cure rate; Mortality \\
\hline ChiCTR2000029757 & $14 / 02 / 2020$ & Recruiting & RCT & $\begin{array}{l}\text { COVID-19 pneumonia } \\
(\mathrm{n}=200)\end{array}$ & $\begin{array}{l}\text { Convalescent plasma }+ \text { Standard } \\
\text { of care }\end{array}$ & Standard of care & Time to clinical improvement \\
\hline ChiCTR2000029850 & $15 / 02 / 2020$ & Recruiting & Non-RCT & COVID-19 pneumonia $(n=20)$ & $\begin{array}{l}\text { Convalescent plasma }+ \text { Standard } \\
\text { of care }\end{array}$ & Standard of care & Mortality \\
\hline ChiCTR2000030046 & $07 / 02 / 2020$ & Recruiting & Non-RCT & $\begin{array}{l}\text { Moderate and severe COVID- } \\
19 \text { pneumonia }(n=10)\end{array}$ & $\begin{array}{l}\text { Anti-2019-nCoV virus inactivated } \\
\text { plasma }\end{array}$ & NA & Clinical symptoms \\
\hline ChiCTR2000030929 & $17 / 03 / 2020$ & Pending & RCT & $\begin{array}{l}\text { Severe COVID-19 pneumonia } \\
(n=60)\end{array}$ & $\begin{array}{l}\text { Anti-SARS-CoV-2 virus inactivated } \\
\text { plasma }\end{array}$ & Ordinary plasma & Clinical symptoms \\
\hline ChiCTR2000030010 & $19 / 02 / 2020$ & Pending & RCT & $\begin{array}{l}\text { Severe COVID-19 pneumonia } \\
(n=100)\end{array}$ & $\begin{array}{l}\text { Anti-SARS-CoV-2 virus inactivated } \\
\text { plasma }\end{array}$ & Ordinary plasma & Clinical symptoms \\
\hline ChiCTR2000030841 & $17 / 02 / 2020$ & Recruiting & Non-RCT & $\begin{array}{l}\text { Severe COVID-19 pneumonia } \\
(\mathrm{n}=10)\end{array}$ & $\begin{array}{l}\text { Immunoglobulin of cured } \\
\text { patients }\end{array}$ & Gama-Globulin & Time to clinical improvement \\
\hline ChiCTR2000029572 & $05 / 02 / 2020$ & Recruiting & RCT & $\begin{array}{l}\text { Severe and critical COVID-19 } \\
\text { pneumonia }(n=30)\end{array}$ & $\begin{array}{l}\text { Umbilical plasma + Standard of } \\
\text { care }\end{array}$ & Standard of care & Pneumonia severity index score \\
\hline
\end{tabular}


Table 7 Clinical trials of anti-inflammatory agents for the treatment of COVID-19 in China from the Chinese Clinical Trial Registry

\begin{tabular}{|c|c|c|c|c|c|c|c|}
\hline Trial ID & $\begin{array}{l}\text { Planned date } \\
\text { of enrolment }\end{array}$ & $\begin{array}{l}\text { Recruitment } \\
\text { status }\end{array}$ & $\begin{array}{l}\text { Study } \\
\text { design }\end{array}$ & $\begin{array}{l}\text { Population (number of } \\
\text { patients) }\end{array}$ & Intervention (dosing, if available) & $\begin{array}{l}\text { Control (dosing, if } \\
\text { available) }\end{array}$ & Primary outcome \\
\hline ChiCTR2000029656 & $14 / 02 / 2020$ & Pending & RCT & $\begin{array}{l}\text { COVID-19 pneumonia } \\
(\mathrm{n}=100)\end{array}$ & $\begin{array}{l}\text { Methylprednisolone injection+ Standard of } \\
\text { care }\end{array}$ & Standard of care & Electrocardiogram; Chest CT \\
\hline ChiCTR2000029386 & $29 / 01 / 2020$ & Recruiting & RCT & $\begin{array}{l}\text { Severe COVID-19 } \\
\text { pneumonia }(n=48)\end{array}$ & $\begin{array}{l}\text { Methylprednisolone injection (1-2mg/kg for } \\
3 \text { days) }\end{array}$ & Standard of care & $\begin{array}{l}\text { Sequential organ failure assessment } \\
\text { score }\end{array}$ \\
\hline ChictR2000030481 & $01 / 03 / 2020$ & Recruiting & RCT & $\begin{array}{l}\text { COVID-19 pneumonia } \\
(\mathrm{n}=200)\end{array}$ & $\begin{array}{l}\text { Group 1: Early corticosteroid use } \\
\text { Group 2: Middle-late corticosteroid use } \\
\text { (after } 5 \text { days of fever) }\end{array}$ & Placebo & Time to nucleic acid negativity \\
\hline ChiCTR2000030170 & $15 / 02 / 2020$ & Recruiting & Non-RCT & $\begin{array}{l}\text { Several and acute } \\
\text { exacerbation COVID-19 } \\
\text { pneumonia ( } n=16)\end{array}$ & $\begin{array}{l}\text { Severe group : Jakotinib hydrochloride (the } \\
\text { first } 3 \text { subjects were given a dose of } 50 \mathrm{mg} \\
\text { Bid for } 7 \text { consecutive days; If no grade } \geq 3 \\
\text { drug-related adverse effects within } 8 \text { days } \\
\text { happened, subsequent subjects were given } \\
100 \mathrm{mg} \text { bid for } 7 \text { day)+Standard therapy } \\
\text { Acute exacerbation group: Jakotinib } \\
\text { hydrochloride (the first } 3 \text { subjects were } \\
\text { given a dose of } 50 \mathrm{mg} \text { Bid for } 7 \text { consecutive } \\
\text { days; If no grade } \geq 3 \text { drug-related adverse } \\
\text { effects within } 8 \text { days happened, subsequent } \\
\text { subjects were given } 100 \mathrm{mg} \text { bid for } 7 \text { day)+ } \\
\text { Standard of care }\end{array}$ & NA & $\begin{array}{l}\text { Severe group: Time to clinical } \\
\text { improvement; } \\
\text { Acute exacerbation group: Time to } \\
\text { clinical recovery }\end{array}$ \\
\hline ChiCTR2000030058 & $10 / 03 / 2020$ & Pending & RCT & $\begin{array}{l}\text { COVID-19 pneumonia with } \\
\text { poorly responsive } \\
\text { Lopinavir-ritonavir }(n=200)\end{array}$ & Leflunomide & Placebo & Time to nucleic acid negativity \\
\hline ChiCTR2000030002 & $15 / 02 / 2020$ & Recruiting & RCT & $\begin{array}{l}\text { Moderate, severe and } \\
\text { critical COVID-19 } \\
\text { pneumonia }(n=60)\end{array}$ & Tranilast + Standard of care & Standard of care & Clinical cure rate \\
\hline
\end{tabular}


Table 8 Clinical trials of additional WMs for the treatment of COVID-19 in China from the Chinese Clinical Trial Registry

\begin{tabular}{|c|c|c|c|c|c|c|c|}
\hline Trial ID & $\begin{array}{l}\text { Planned date } \\
\text { of enrollment }\end{array}$ & $\begin{array}{l}\text { Recruitment } \\
\text { status }\end{array}$ & $\begin{array}{l}\text { Study } \\
\text { design }\end{array}$ & Population (number of patients) & $\begin{array}{l}\text { Intervention (dosing, if } \\
\text { available) }\end{array}$ & $\begin{array}{l}\text { Control (dosing, if } \\
\text { available) }\end{array}$ & Primary outcome \\
\hline ChiCTR2000030892 & $06 / 03 / 2020$ & Recruiting & RCT & Severe COVID-19 $(n=40)$ & Pirfenidone & Placebo & Pulmonary fibrosis score \\
\hline ChiCTR2000030333 & $04 / 03 / 2020$ & Recruiting & RCT & $\begin{array}{l}\text { Several and critical COVID-19 } \\
\text { pneumonia }(n=292)\end{array}$ & $\begin{array}{l}\text { Pirfenidone }(400 \mathrm{mg}, \mathrm{tid})+ \\
\text { Standard of care }\end{array}$ & Standard of care & Chest CT \\
\hline ChiCTR2000030539 & $06 / 03 / 2020$ & Pending & Non-RCT & COVID-19 pneumonia $(n=40)$ & $3 \%$ hydrogen peroxide gargle & Placebo & Rate of nucleic acid negativity \\
\hline ChiCTR2000030471 & $02 / 03 / 2020$ & Recruiting & RCT & $\begin{array}{l}\text { Moderate COVID-19 pneumonia } \\
(n=394)\end{array}$ & $\begin{array}{l}\text { Lipoic acid injection + } \\
\text { Standard of care }\end{array}$ & Standard of care & Rate of progression \\
\hline ChicTR2000030398 & $27 / 02 / 2020$ & Pending & RCT & COVID-19 pneumonia $(n=340)$ & $\begin{array}{l}\text { Bismuth potassium citrate ( } 2 \\
\text { capsules, bid) }\end{array}$ & Placebo & Rate of nucleic acid negativity \\
\hline ChictR2000029867 & $15 / 02 / 2020$ & Recruiting & RCT & COVID-19 pneumonia $(n=520)$ & Carrimycin & Lopinavir-ritonavir & Rate of nucleic acid negativity \\
\hline
\end{tabular}

The standard of care followed the guidance of the "Diagnosis and Treatment Protocol for COVID-19 Pneumonia" published by the Chinese National Health Commission [39].

Nucleic acid negativity is defined by reverse transcription polymerase chain reaction (RT-PCR)

Rate of composite adverse outcomes is defined as SpO2 $<=93 \%$ without oxygen supplementation, or PaO2/FiO2 $<=300 \mathrm{mmHg}$, or respiratory rate $(R R)<=30$ breaths per minute

Time to clinical recovery is defined as the normal body temperature (underarm temperature $<=36.9$ degrees $C$ ) and cough relief (evaluated by the cough symptom score scale) in the duration of at least 72 hours from the start of study treatment

WMs : Western medicines; RCT: Randomized clinical trial; COVID-19: Coronavirus Disease 2019; NA: Not available; bid: twice daily; tid: three times a day; CT: computed tomography 
Table 9 Clinical trials of WM combination therapy for the treatment of COVID-19 in China from the Chinese Clinical Trial Registry

\begin{tabular}{|c|c|c|c|c|c|c|c|}
\hline Trial ID & $\begin{array}{l}\text { Planned date } \\
\text { of enrollment }\end{array}$ & $\begin{array}{l}\text { Recruitment } \\
\text { status }\end{array}$ & $\begin{array}{l}\text { Study } \\
\text { design }\end{array}$ & $\begin{array}{l}\text { Population (number } \\
\text { of patients) }\end{array}$ & Intervention (dosing, if available) & $\begin{array}{l}\text { Control (dosing, if } \\
\text { available) }\end{array}$ & Primary outcome \\
\hline ChiCTR2000030535 & $20 / 02 / 2020$ & Recruiting & RCT & $\begin{array}{l}\text { Moderate and } \\
\text { severe COVID-19 } \\
\text { pneumonia }(n=100)\end{array}$ & $\begin{array}{l}\text { Ebastine (10mg bid) + Nterferon-alpha aerosol } \\
\text { inhalation ( } 5 \text { million U bid) + Lopinavir ( } 200 \mathrm{mg} \text {, } \\
\text { bid) }\end{array}$ & $\begin{array}{l}\text { Nterferon-alpha aerosol } \\
\text { inhalation }(5 \mathrm{million} \cup \mathrm{bid})+ \\
\text { Lopinavir }(200 \mathrm{mg}, \text { bid })\end{array}$ & Clinical cure rate; Chest CT \\
\hline ChiCTR2000030894 & $01 / 03 / 2020$ & Recruiting & RCT & $\begin{array}{l}\text { Moderate and } \\
\text { severe COVID-19 } \\
\text { pneumonia ( } n=150)\end{array}$ & Favipiravir +Tocilizumab & $\begin{array}{l}\text { Group 1: Favipiravir } \\
\text { Group 2: Tocilizumab }\end{array}$ & Clinical cure rate \\
\hline ChiCTR2000030987 & $05 / 03 / 2020$ & Recruiting & RCT & $\begin{array}{l}\text { COVID-19 } \\
\text { pneumonia }(n=150)\end{array}$ & $\begin{array}{l}\text { Group 1: Favipiravir + Chloroquine } \\
\text { phosphatetablets; } \\
\text { Group 2: Favipiravir }\end{array}$ & Placebo & Time to clinical recovery \\
\hline ChiCTR2000030922 & $26 / 02 / 2020$ & Recruiting & RCT & $\begin{array}{l}\text { Mild and Moderate } \\
\text { COVID-19 } \\
\text { pneumonia }(n=30)\end{array}$ & $\begin{array}{l}\text { Long-acting interferon alpha-2a }(135 \mu \mathrm{g})+ \\
\text { ribavirin }\end{array}$ & Umifenovir + ribavirin & $\begin{array}{l}\text { Rate of nucleic acid negativity; } \\
\text { Mortality }\end{array}$ \\
\hline ChiCTR2000029759 & $15 / 02 / 2020$ & $\begin{array}{l}\text { Temporary } \\
\text { halt }\end{array}$ & RCT & $\begin{array}{l}\text { COVID-19 } \\
\text { pneumonia }(n=60)\end{array}$ & Lopinavir-ritonavir+ interferon & Umifenovir +interferon & Time to clinical recovery \\
\hline ChiCTR2000029387 & $25 / 01 / 2020$ & Recruiting & RCT & $\begin{array}{l}\text { Mild and moderate } \\
\text { COVID-19 } \\
\text { pneumonia }(n=108)\end{array}$ & Ribavirin+ Interferon alpha-1b & $\begin{array}{l}\text { Lopinavir-ritonavir + } \\
\text { Interferon alpha-1b }\end{array}$ & Time to nucleic acid negativity \\
\hline ChiCTR2000030262 & $01 / 02 / 2020$ & Recruiting & Non-RCT & $\begin{array}{l}\text { COVID-19 } \\
\text { pneumonia }(n=30)\end{array}$ & $\begin{array}{l}\text { Group 1: Anti-viral drugs + Type I interferon + } \\
\text { Inflammation inhibitor TFF2 (Once for one day); } \\
\text { Group 2: Anti-viral drugs + Type I interferon+ } \\
\text { Inflammation inhibitor TFF2 (Once for two } \\
\text { days) }\end{array}$ & NA & Viral load \\
\hline ChiCTR2000030703 & $10 / 03 / 2020$ & Recruiting & RCT & $\begin{array}{l}\text { Moderate and } \\
\text { severe COVID-19 } \\
\text { pneumonia }(n=40)\end{array}$ & Lxekizumab + Antiviral therapy & Antiviral therapy & Chest CT \\
\hline ChiCTR2000029580 & $31 / 01 / 2020$ & Recruiting & RCT & $\begin{array}{l}\text { Severe and critical } \\
\text { COVID-19 } \\
\text { pneumonia }(n=70)\end{array}$ & Mesenchymal stem cells + Ruxolitinib & Standard of care & Safety \\
\hline ChiCTR2000029600 & $30 / 01 / 2020$ & Recruiting & Non-RCT & $\begin{array}{l}\text { COVID-19 } \\
\text { pneumonia }(n=90)\end{array}$ & $\begin{array}{l}\text { Group 1: Alpha-interferon atomization } \\
\text { Group 2: Lopinavir-ritonavir + Alpha-interferon } \\
\text { Group 3: Favipiravir + alpha-interferon } \\
\text { atomization }\end{array}$ & NA & $\begin{array}{l}\text { Time to and rate of nucleic acid } \\
\text { negativity; Chest CT }\end{array}$ \\
\hline ChiCTR2000029431 & $29 / 01 / 2020$ & Recruiting & RCT & $\begin{array}{l}\text { COVID-19 } \\
\text { pneumonia }(n=45)\end{array}$ & $\begin{array}{l}\text { Group 1: Ankylosaurus + Standard of care } \\
\text { Group 2: Ankylosaurus + Type I macrophages } \\
\text { therapy + Standard of care }\end{array}$ & Standard of care & Chest CT \\
\hline
\end{tabular}


The standard of care followed the guidance of the "Diagnosis and Treatment Protocol for COVID-19 Pneumonia" published by the Chinese National Health Commission [39]. Nucleic acid negativity is defined by reverse transcription polymerase chain reaction (RT-PCR)

Rate of composite adverse outcomes is defined as $\mathrm{SpO} 2<=93 \%$ without oxygen supplementation, or PaO2/FiO2 $<=300 \mathrm{mmHg}$, or respiratory rate (RR) $<=30$ breaths per minute

Time to clinical recovery is defined as the normal body temperature (underarm temperature $<=36.9$ degrees $C$ ) and cough relief (evaluated by the cough symptom score scale) in the duration of at least 72 hours from

the start of study treatment

WM: Western medicine; RCT: Randomized clinical trial; COVID-19: Coronavirus Disease 2019; NA: Not available; bid: twice daily; CT: computed tomography

Wh: Westrite 
Table 10 Clinical trials of TCMs for the treatment of COVID-19 in China from the Chinese Clinical Trial Registry

\begin{tabular}{|c|c|c|c|c|c|c|c|}
\hline Trial ID & $\begin{array}{l}\text { Planned } \\
\text { date of } \\
\text { enrollment }\end{array}$ & $\begin{array}{l}\text { Recruitment } \\
\text { status }\end{array}$ & $\begin{array}{l}\text { Study } \\
\text { design }\end{array}$ & $\begin{array}{l}\text { Population (number of } \\
\text { patients) }\end{array}$ & $\begin{array}{l}\text { Intervention (dosing, if } \\
\text { available) }\end{array}$ & Control & Primary outcome \\
\hline ChiCTR2000029381 & $24 / 01 / 2020$ & Pending & Non-RCT & $\begin{array}{l}\text { Severe COVID-19 pneumonia } \\
(\mathrm{n}=400)\end{array}$ & Xue-Bi-Jing injection & $\begin{array}{l}\text { Standard of } \\
\text { care }\end{array}$ & Pneumonia severity index score \\
\hline ChiCTR2000029432 & $01 / 02 / 2020$ & Pending & Non-RCT & COVID-19 pneumonia $(n=72)$ & $\begin{array}{l}\text { Tan-Re-Qing injection } \\
(40 \mathrm{ml}, \mathrm{qd})\end{array}$ & NA & Clinical symptoms (temperature) \\
\hline ChiCTR2000029756 & $15 / 02 / 2020$ & Recruiting & RCT & $\begin{array}{l}\text { COVID-19 pneumonia } \\
(\mathrm{n}=238)\end{array}$ & Xi-Yan-Ping injection & $\begin{array}{l}\text { Alpha- } \\
\text { interferon }\end{array}$ & Clinical symptoms \\
\hline ChiCTR2000029822 & $07 / 02 / 2020$ & Recruiting & RCT & $\begin{array}{l}\text { COVID-19 pneumonia } \\
(n=110)\end{array}$ & Honeysuckle decoction & Placebo & Clinical cure rate \\
\hline ChiCTR2000029855 & $15 / 02 / 2020$ & Recruiting & RCT & $\begin{array}{l}\text { Moderate COVID-19 } \\
\text { pneumonia }(n=180)\end{array}$ & $\begin{array}{l}\text { Group 1: Qing-Fei } \\
\text { prescription } \\
\text { Group 2: Qing-Fei } \\
\text { prescription + Compound } \\
\text { houttuynia mixture }\end{array}$ & $\begin{array}{l}\text { Standard of } \\
\text { care }\end{array}$ & $\begin{array}{l}\text { TCM symptom score; The time and rate of nucleic acid } \\
\text { negativity }\end{array}$ \\
\hline ChiCTR2000030003 & $19 / 02 / 2020$ & Pending & RCT & $\begin{array}{l}\text { COVID-19 pneumonia } \\
(\mathrm{n}=480)\end{array}$ & $\begin{array}{l}\text { Group 1: TCM prescription } \\
\text { No. } 1 \text { and } 2 \\
\text { Group 2: Gan-Ke-Shuang- } \\
\text { Qing capsule } \\
\text { Group 3: Shuang-Huang- } \\
\text { Lian liquid }\end{array}$ & NA & Days of hospitalization; Clinical symptoms \\
\hline ChiCTR2000030751 & $25 / 01 / 2020$ & Pending & Non-RCT & COVID-19 pneumonia $(n=60)$ & $\begin{array}{l}\text { Traditional Mongolian } \\
\text { Medicine }\end{array}$ & NA & Chest CT; Time to and rate of nucleic acid negativity \\
\hline ChiCTR2000030804 & $01 / 02 / 2020$ & Recruiting & RCT & $\begin{array}{l}\text { Moderate COVID-19 } \\
\text { pneumonia }(n=128)\end{array}$ & $\begin{array}{l}\text { Exocarpium citri grandis } \\
\text { phlegm cough solution }\end{array}$ & Placebo & \\
\hline ChiCTR2000030988 & $23 / 03 / 2020$ & Pending & RCT & $\begin{array}{l}\text { Mild and moderate COVID- } \\
19 \text { pneumonia }(n=204)\end{array}$ & Hua-Shi Bai-Du granules & $\begin{array}{l}\text { Standard of } \\
\text { care }\end{array}$ & Days of hospitalization \\
\hline
\end{tabular}

The standard of care followed the guidance of the "Diagnosis and Treatment Protocol for COVID-19 Pneumonia" published by the Chinese National Health Commission [39].

Nucleic acid negativity is defined by reverse transcription polymerase chain reaction (RT-PCR)

Rate of composite adverse outcomes is defined as $\mathrm{SpO} 2<=93 \%$ without oxygen supplementation, or PaO2/FiO2 $<=300 \mathrm{mmHg}$, or respiratory rate (RR) $<=30$ breaths per minute

Time to clinical recovery is defined as the normal body temperature (underarm temperature $<=36.9$ degrees $C$ ) and cough relief (evaluated by the cough symptom score scale) in the duration of at least 72 hours from the start of study treatment

TCM: Traditional Chinses medicines; RCT: Randomized clinical trial; COVID-19: Coronavirus Disease 2019; NA: Not available; qd: Once a day; CT: computed tomography 
Table 11 Clinical trials of combination therapy of TCMs and WMs for the treatment of COVID-19 in China from the Chinese Clinical Trial Registry

\begin{tabular}{|c|c|c|c|c|c|c|c|}
\hline Trial ID & $\begin{array}{l}\text { Date of } \\
\text { enrolment }\end{array}$ & $\begin{array}{l}\text { Recruitment } \\
\text { status }\end{array}$ & $\begin{array}{l}\text { Study } \\
\text { design }\end{array}$ & $\begin{array}{l}\text { Population (number } \\
\text { of patients) }\end{array}$ & Intervention (dosing, if available) & Control & Primary outcome \\
\hline ChiCTR2000029434 & $01 / 02 / 2020$ & Recruiting & RCT & $\begin{array}{l}\text { COVID-19 pneumonia } \\
(n=240)\end{array}$ & $\begin{array}{l}\text { Lian-Hua-Qing-Wen Capsules (4 } \\
\text { capsules, tid) + Standard of care }\end{array}$ & Standard of care & Clinical symptoms \\
\hline ChiCTR2000029589 & $06 / 02 / 2020$ & Recruiting & Non-RCT & $\begin{array}{l}\text { Moderate COVID-19 } \\
\text { pneumonia }(n=60)\end{array}$ & Re-Du-Ning injection + Standard of care & Standard of care & Clinical symptoms(temperature) \\
\hline ChiCTR2000029605 & $06 / 02 / 2020$ & Recruiting & RCT & $\begin{array}{l}\text { COVID-19 pneumonia } \\
(n=400)\end{array}$ & $\begin{array}{l}\text { Lower dose group: Shuang-Huang-Lian } \\
\text { ( } 2 \text { bottles, tid) + Standard of care } \\
\text { Lower dose group: Shuang-Huang-Lian } \\
\text { ( } 4 \text { bottles, tid) + Standard of care; } \\
\text { Lower dose group: Shuang-Huang-Lian } \\
\text { ( } 6 \text { bottles, tid) + Standard of care }\end{array}$ & Standard of care & Time to clinical recovery \\
\hline ChiCTR2000029742 & $10 / 02 / 2020$ & Recruiting & RCT & $\begin{array}{l}\text { COVID-19 pneumonia } \\
(n=90)\end{array}$ & $\begin{array}{l}\text { Moderate patients: } \\
\text { Group 1: Sodium Aescinate Injection + } \\
\text { Standard of care } \\
\text { Severe patients: } \\
\text { Group 1: Sodium Aescinate injection + } \\
\text { Standard of care }\end{array}$ & $\begin{array}{l}\text { Moderate } \\
\text { patients: } \\
\text { Group 1: Standard } \\
\text { of care Severe } \\
\text { patients: } \\
\text { Group 1: Standard } \\
\text { of care } \\
\text { Group 2: } \\
\text { Hormonotherapy + } \\
\text { Standard of care }\end{array}$ & Chest CT \\
\hline ChiCTR2000029768 & $12 / 02 / 2020$ & Recruiting & RCT & $\begin{array}{l}\text { COVID-19 pneumonia } \\
(n=60)\end{array}$ & $\begin{array}{l}\text { Diammonium Glycyrrhizinate Enteric- } \\
\text { coated Capsules }(150 \mathrm{mg} \text {, tid) +Vitamin } \\
\text { C tablets + Standard of care }\end{array}$ & Standard of care & Time to clinical recovery \\
\hline ChiCTR2000029769 & $15 / 02 / 2020$ & Pending & RCT & $\begin{array}{l}\text { Severe COVID-19 } \\
\text { pneumonia }(n=40)\end{array}$ & $\begin{array}{l}\text { Ba-Bao-Dan (6 capsules, bid) + } \\
\text { Standard of care }\end{array}$ & Standard of care & 28-day survival \\
\hline ChiCTR2000029780 & $14 / 02 / 2020$ & Recruiting & RCT & $\begin{array}{l}\text { Severe COVID-19 } \\
\text { pneumonia }(n=160)\end{array}$ & $\begin{array}{l}\text { Shen-Qi-Fu-Zheng injection + Standard } \\
\text { of care }\end{array}$ & Standard of care & Time to clinical recovery \\
\hline ChiCTR2000029781 & $14 / 02 / 2020$ & Recruiting & RCT & $\begin{array}{l}\text { Severe COVID-19 } \\
\text { pneumonia }(n=160)\end{array}$ & $\begin{array}{l}\text { Kang-Bing-Du granules + Standard of } \\
\text { care }\end{array}$ & Standard of care & Clinical symptoms(temperature) \\
\hline ChiCTR2000029813 & $14 / 02 / 2020$ & Recruiting & RCT & $\begin{array}{l}\text { Mild and moderate } \\
\text { COVID-19 pneumonia } \\
(n=72)\end{array}$ & $\begin{array}{l}\text { Tan-Re-Qing Capsules ( } 3 \text { capsules, tid) } \\
+ \text { Standard of care }\end{array}$ & Standard of care & $\begin{array}{l}\text { Time to and rate of nucleic acid negativity } \\
\text { Clinical symptoms(temperature) }\end{array}$ \\
\hline ChiCTR2000029819 & $11 / 02 / 2020$ & Recruiting & Non-RCT & $\begin{array}{l}\text { COVID-19 pneumonia } \\
(n=80)\end{array}$ & Ba-Bao-Dan + Standard of care & Standard of care & Viral load; Chest CT; Clinical symptoms \\
\hline ChiCTR2000029869 & $10 / 02 / 2020$ & Pending & RCT & $\begin{array}{l}\text { COVID-19 pneumonia } \\
(n=300)\end{array}$ & $\begin{array}{l}\text { Truncated Torsion Formula + Standard } \\
\text { of care }\end{array}$ & Standard of care & Chest CT \\
\hline ChiCTR2000029991 & $18 / 02 / 2020$ & Recruiting & RCT & $\begin{array}{l}\text { Mild and moderate } \\
\text { COVID-19 pneumonia } \\
(n=72)\end{array}$ & $\begin{array}{l}\text { Group 1: Ke-Su-Ting syrup }(20 \mathrm{ml} \text {, tid })+ \\
\text { Standard of care Group 2: Ke-Qing } \\
\text { capsule ( } 3 \text { pills, tid })+ \text { Standard of care }\end{array}$ & Standard of care & Clinical symptoms (cough) \\
\hline ChiCTR2000029947 & 01/03/2020 & Pending & RCT & $\begin{array}{l}\text { COVID-19 pneumonia } \\
(n=200)\end{array}$ & $\begin{array}{l}\text { Qing-Yi No. } 4 \text { compound + Standard of } \\
\text { care }\end{array}$ & Standard of care & Lung function \\
\hline
\end{tabular}




\begin{tabular}{|c|c|c|c|c|c|c|c|}
\hline ChiCTR2000029954 & $30 / 04 / 2020$ & Recruiting & RCT & $\begin{array}{l}\text { COVID-19 pneumonia } \\
(n=300)\end{array}$ & $\begin{array}{l}\text { Group 1: Honeysuckle oral liquid (60ml } \\
\text { each time, tid) + Standard of care } \\
\text { Group 2: Honeysuckle oral liquid } \\
\text { (180ml each time, tid) + Standard of } \\
\text { care }\end{array}$ & Standard of care & $\begin{array}{l}\text { Time to clinical recovery; Pneumonia severity } \\
\text { index score }\end{array}$ \\
\hline ChiCTR2000029993 & $20 / 02 / 2020$ & Recruiting & RCT & $\begin{array}{l}\text { Mild, moderate and } \\
\text { severe COVID-19 } \\
\text { pneumonia }(n=40)\end{array}$ & $\begin{array}{l}\text { Liu-Shen Capsule }+ \text { Arbidol } \\
\text { Hydrochloride Tablets+ Standard of } \\
\text { care }\end{array}$ & Standard of care & Clinical symptoms \\
\hline ChiCTR2000030022 & $22 / 02 / 2020$ & Pending & RCT & $\begin{array}{l}\text { Mild and common } \\
\text { COVID-19 pneumonia } \\
(n=100)\end{array}$ & $\begin{array}{l}\text { Pediatric Hua-Tan-Zhi-Ke granules + } \\
\text { Standard of care }\end{array}$ & Standard of care & $\begin{array}{l}\text { Time to nucleic acid negativity; Chest CT Rate } \\
\text { of progression }\end{array}$ \\
\hline ChiCTR2000030043 & $21 / 02 / 2020$ & Pending & RCT & $\begin{array}{l}\text { COVID-19 pneumonia } \\
(n=300)\end{array}$ & Shen-Fu injection + Standard of care & Standard of care & $\begin{array}{l}\text { Pneumonia severity index score; Incidence of } \\
\text { new organ dysfunction }\end{array}$ \\
\hline ChiCTR2000030117 & $15 / 02 / 2020$ & Recruiting & RCT & $\begin{array}{l}\text { COVID-19 pneumonia } \\
(n=348)\end{array}$ & Xi-Yan-Ping injection + Standard of care & $\begin{array}{l}\text { Lopinavir-ritonavir } \\
+ \text { + Alpha-interferon }\end{array}$ & Time to clinical recovery \\
\hline ChiCTR2000030166 & $25 / 02 / 2020$ & Pending & RCT & $\begin{array}{l}\text { COVID-19 pneumonia } \\
(n=20)\end{array}$ & $\begin{array}{l}\text { Qing-Wen-Bai-Du-Yin formula granules } \\
+ \text { Lopinavir-ritonavir + Interferon } \alpha 2 b \\
\text { injection }\end{array}$ & $\begin{array}{l}\text { Lopinavir-ritonavir } \\
+ \text { Recombinant } \\
\text { human interferon } \\
\text { alpha } 2 \text { b injection }\end{array}$ & Chest CT \\
\hline ChiCTR2000030215 & $26 / 02 / 2020$ & Pending & RCT & $\begin{array}{l}\text { COVID-19 pneumonia } \\
(n=120)\end{array}$ & $\begin{array}{l}\text { Group 1: Kang-Guan No. } 1+\text { Standard } \\
\text { of care (Mild COVID-19 pneumonia); } \\
\text { Group 2: Kang-Guan No. } 2+\text { Standard } \\
\text { of care (Moderate COVID-19 } \\
\text { pneumonia); } \\
\text { Group 2: Kang-Guan No. } 3 \text { + Standard } \\
\text { of care (Severe COVID-19 pneumonia) }\end{array}$ & Standard of care & Chest CT \\
\hline ChiCTR2000030218 & $22 / 01 / 2020$ & Recruiting & RCT & $\begin{array}{l}\text { COVID-19 pneumonia } \\
(\mathrm{n}=80)\end{array}$ & $\begin{array}{l}\text { Moderate patients } \\
\text { Group 1: Xi-Yan-Ping injection+ } \\
\text { lopinavir-ritonavir } \\
\text { Severe patients } \\
\text { Group 2: Xi-Yan-Ping injection+ } \\
\text { lopinavir-ritonavir }\end{array}$ & $\begin{array}{l}\text { Moderate patients } \\
\text { Group 1: lopinavir- } \\
\text { ritonavir }\end{array}$ & $\begin{array}{l}\text { Time to clinical recovery; Pneumonia Severity } \\
\text { Index score }\end{array}$ \\
\hline ChiCTR2000030255 & $01 / 03 / 2020$ & Pending & RCT & $\begin{array}{l}\text { Moderate and severe } \\
\text { COVID-19 pneumonia } \\
(n=300)\end{array}$ & $\begin{array}{l}\text { Jing-Yin Granule ( } 2 \text { packs, tid) + } \\
\text { Standard of care }\end{array}$ & Standard of care & Time to clinical recovery \\
\hline ChiCTR2000030388 & $18 / 02 / 2020$ & Recruiting & RCT & $\begin{array}{l}\text { Severe COVID-19 } \\
\text { pneumonia }(n=60)\end{array}$ & $\begin{array}{l}\text { Xue-Bi-Jing injection }(50 \mathrm{ml} \text {, bid })+ \\
\text { Standard of care }\end{array}$ & Standard of care & $\begin{array}{l}\text { Time spent on the ventilator; Mortality; Time } \\
\text { to nucleic acid negativity }\end{array}$ \\
\hline ChiCTR2000030469 & $27 / 02 / 2020$ & Recruiting & RCT & $\begin{array}{l}\text { Moderate and severe } \\
\text { COVID-19 pneumonia } \\
(n=96)\end{array}$ & Liu-Shen-Wan + Standard of care & Standard of care & Clinical symptoms (temperature) \\
\hline ChiCTR2000030479 & $26 / 02 / 2020$ & Pending & RCT & $\begin{array}{l}\text { Common COVID-19 } \\
\text { pneumonia }(n=100)\end{array}$ & $\begin{array}{l}\text { Yi-Qi-Hua-Shi-Jie-Du-Fang (150mL, bid) } \\
\text { + Standard of care }\end{array}$ & Standard of care & Time to and rate of nucleic acid negativity \\
\hline ChicTR2000030490 & $01 / 02 / 2020$ & Recruiting & Non-RCT & $\begin{array}{l}\text { Moderate COVID-19 } \\
\text { pneumonia }(n=100)\end{array}$ & $\begin{array}{l}\text { Diammonium glycyrrhizinate enteric- } \\
\text { coated capsule + Hydrogen-rich water }\end{array}$ & NA & Clinical cure rate \\
\hline ChiCTR2000030518 & $29 / 02 / 2020$ & Recruiting & RCT & $\begin{array}{l}\text { COVID-19 pneumonia } \\
(n=60)\end{array}$ & $\begin{array}{l}\text { Zedoary Turmeric Oil }(0.2 \mathrm{~g}, \mathrm{qd})+ \\
\text { Standard of care }\end{array}$ & Standard of care & $\begin{array}{l}\text { Time to and rate of nucleic acid negativity; } \\
\text { Time to clinical improvement; Chest CT }\end{array}$ \\
\hline
\end{tabular}

.

8

(⿸丆口

.

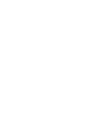




\begin{tabular}{|c|c|c|c|c|c|c|c|}
\hline ChiCTR2000030522 & $09 / 03 / 2020$ & Recruiting & RCT & $\begin{array}{l}\text { COVID-19 pneumonia } \\
(\mathrm{n}=100)\end{array}$ & $\begin{array}{l}\text { Ma-Xing-Gan-Shi decoction + Standard } \\
\text { of care }\end{array}$ & Standard of care & Time to clinical recovery \\
\hline ChiCTR2000030836 & $01 / 02 / 2020$ & Pending & Non-RCT & $\begin{array}{l}\text { Common COVID-19 } \\
\text { pneumonia }(n=300)\end{array}$ & $\begin{array}{l}\text { Truncated Torsion Formula + Standard } \\
\text { of care }\end{array}$ & Standard of care & 14 days outcome of the subjects; Chest CT \\
\hline ChiCTR2000030864 & $01 / 02 / 2020$ & Recruiting & Non-RCT & $\begin{array}{l}\text { COVID-19 pneumonia } \\
(n=50)\end{array}$ & $\begin{array}{l}\text { Qing-Fei-Pai-Du decoction + Standard } \\
\text { of care }\end{array}$ & NA & $\begin{array}{l}\text { Viral load; Chest CT; Routine TCM symptom } \\
\text { score }\end{array}$ \\
\hline ChiCTR2000030923 & $15 / 02 / 2020$ & Recruiting & RCT & $\begin{array}{l}\text { COVID-19 pneumonia } \\
(\mathrm{n}=400)\end{array}$ & $\begin{array}{l}\text { Group 1: TCM formula } 1 \text { or TCM } \\
\text { formula } 2 \text { (Suspected case); } \\
\text { Group 2: TCM formula } 3 \text { or TCM } \\
\text { formula } 4 \text { or TCM formula } 5 \text { or TCM } \\
\text { formula } 6+\text { Standard of care (confirmed } \\
\text { cases); }\end{array}$ & $\begin{array}{l}\text { Group 1: None; } \\
\text { Group 2: Standard } \\
\text { of care }\end{array}$ & Clinical symptoms \\
\hline \multicolumn{8}{|c|}{$\begin{array}{l}\text { Cases); } \\
\text { The standard of care followed the guidance of the "Diagnosis and Treatment Protocol for COVID-19 Pneumonia" published by the Chinese National Health Commission [39]. } \\
\text { Nucleic acid negativity is defined by reverse transcription polymerase chain reaction (RT-PCR) } \\
\text { Rate of composite adverse outcomes is defined as SpO2<=93\% without oxygen supplementation, or PaO2/FiO2 }<=300 \mathrm{mmH} \text {, or respiratory rate (RR) <=30 breaths per minute } \\
\text { Time to clinical recovery is defined as the normal body temperature (underarm temperature }<=36.9 \text { degrees C) and cough relief (evaluated by the cough symptom score scale) in the duration of at least } 72 \text { hours from } \\
\text { the start of study treatment } \\
\text { TCM: Traditional Chinses medicines; RCT: Randomized clinical trial; COVID-19: Coronavirus Disease 2019; NA: Not available; qd: Once a day; bid: twice daily; tid: three times a day; CT: computed tomography }\end{array}$} \\
\hline
\end{tabular}

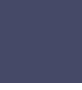

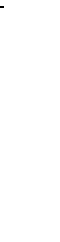


Table 12 Observational studies of pharmacological treatments for COVID-19 in China from the Chinese Clinical Trial Registry

\begin{tabular}{|c|c|c|c|c|c|c|c|}
\hline Trial ID & Date of enrollment & Recruitment status & Study design & $\begin{array}{l}\text { Population (number of } \\
\text { patients) }\end{array}$ & $\begin{array}{l}\text { Exposure (dosing, if } \\
\text { available) }\end{array}$ & $\begin{array}{l}\text { Reference (dosing, if } \\
\text { available) }\end{array}$ & Primary outcome \\
\hline ChiCTR2000030883 & $18 / 02 / 2020$ & Recruiting & Case series & $\begin{array}{l}\text { COVID-19 pneumonia } \\
(n=100)\end{array}$ & $\begin{array}{l}\text { Qing-Fei detoxification } \\
\text { decoction (mixture) }\end{array}$ & NA & $\begin{array}{l}\text { Clinical symptom } \\
\text { (temprature and } \\
\text { respiration); Chest CT; } \\
\text { Time to nucleic acid } \\
\text { negativity }\end{array}$ \\
\hline ChiCTR2000030866 & $01 / 02 / 2020$ & Recruiting & Case series & $\begin{array}{l}\text { Severe and critical } \\
\text { COVID-19 pneumonia } \\
(n=30)\end{array}$ & $\begin{array}{l}\text { human umbilical cord } \\
\text { derived mesenchymal } \\
\text { stem cells }\left(1 \times 10^{\wedge} 6\right. \\
\text { UCMSCs } / \mathrm{kg} / \text { time on } \\
\text { day } 0,3,6)+ \text { Standard } \\
\text { of care }\end{array}$ & NA & $\begin{array}{l}\text { Rate of disesae } \\
\text { progression; Mortality }\end{array}$ \\
\hline ChiCTR2000030854 & $22 / 01 / 2020$ & Completed & Cohort study & $\begin{array}{l}\text { COVID-19 pneumonia } \\
(\mathrm{n}=237)\end{array}$ & $\begin{array}{l}\text { GroAbidor + Lopinavir- } \\
\text { ritonavir + } \\
\text { Recombinant } \\
\text { interferon alpha-2b }\end{array}$ & $\begin{array}{l}\text { Lopinavir-ritonavir + } \\
\text { Recombinant } \\
\text { interferon alpha-2b }\end{array}$ & Blood routine test \\
\hline ChiCTR2000030806 & $01 / 02 / 2020$ & Recruiting & Case series & $\begin{array}{l}\text { COVID-19 pneumonia } \\
(\mathrm{n}=20)\end{array}$ & $\begin{array}{l}\text { Qing-Fei detoxification } \\
\text { soup + ulinastatin } \\
\text { (200000 U Bid) }\end{array}$ & NA & Blood routine test \\
\hline ChiCTR2000030389 & $29 / 02 / 2020$ & Recruiting & Cohort study & $\begin{array}{l}\text { COVID-19 pneumonia } \\
(n=120)\end{array}$ & $\begin{array}{l}\text { Triple energizer } \\
\text { treatment + Standard } \\
\text { of care }\end{array}$ & Standard of care & $\begin{array}{l}\text { Chest CT; TCM } \\
\text { symptoms }\end{array}$ \\
\hline ChiCTR2000029637 & $07 / 02 / 2020$ & Pending & Cohort study & $\begin{array}{l}\text { COVID-19 pneumonia } \\
(n=100)\end{array}$ & $\begin{array}{l}\text { Xin-Guan-1 formula + } \\
\text { Standard of care }\end{array}$ & Standard of care & $\begin{array}{l}\text { Time to remission and } \\
\text { disappearance of } \\
\text { primary symptoms }\end{array}$ \\
\hline
\end{tabular}

The standard of care followed the guidance of the "Diagnosis and Treatment Protocol for COVID-19 Pneumonia" published by the Chinese National Health Commission [39].

Nucleic acid negativity is defined by reverse transcription polymerase chain reaction (RT-PCR)

Rate of composite adverse outcomes is defined as $\mathrm{SpO} 2<=93 \%$ without oxygen supplementation, or PaO2/FiO2 $<=300 \mathrm{mmHg}$, or respiratory rate $(R R)<=30$ breaths per minute

Time to clinical recovery is defined as the normal body temperature (underarm temperature $<=36.9$ degrees C) and cough relief (evaluated by the cough symptom score scale) in the duration of at least 72 hours from the start of study treatment

TCM: Traditional Chinses medicines; WM: Western medicines; RCT: Randomized clinical trial; COVID-19: Coronavirus Disease 2019; NA: Not available; CT: computed tomography 
Table 13 Published results of clinical trials conducted in China

\begin{tabular}{|c|c|c|c|c|c|}
\hline Author year & $\begin{array}{l}\text { Population (number } \\
\text { of patients) }\end{array}$ & $\begin{array}{l}\text { Study } \\
\text { design }\end{array}$ & Intervention/Exposure (dosing, if available) & $\begin{array}{l}\text { Comparator/Reference (dosing, if } \\
\text { available) }\end{array}$ & Primary outcomes \\
\hline \multicolumn{6}{|l|}{ CNKI } \\
\hline Fu 2020 [12] & $\begin{array}{l}\text { COVID-19 pneumonia } \\
(n=37)\end{array}$ & RCT & $\begin{array}{l}\text { Tou-Jie-Qu-Wen granules (bid, } 15 \text { days) + } \\
\text { Umifenovir ( } 200 \mathrm{mg} \text {, tid, } 10 \text { days) }\end{array}$ & Umifenovir (200 mg, tid, 10 days) & $\begin{array}{l}\text { Significant improvement in TCM syndrome score, the } \\
\text { absolute value of lymphocyte, } C \text { reactive protein value } \\
(P<0.05)\end{array}$ \\
\hline Wang 2020 [13] & $\begin{array}{l}\text { Moderate COVID-19 } \\
\text { pneumonia }(n=60)\end{array}$ & RCT & $\begin{array}{l}\text { Lopinavir-ritonavir ( } 400 \mathrm{mg} / 100 \mathrm{mg} \text {, bid, } 7 \text { - } \\
10 \text { days) + Lian-Hua-Qing-Wen capsule ( } 4 \\
\text { tablets, tid) + Interferon- } \alpha \text { ( } 500 \text { million } \\
\text { units, bid) }\end{array}$ & $\begin{array}{l}\text { Lian-Hua-Qing-Wen capsule (4 } \\
\text { tablets, tid) + interferon- } \alpha(500 \\
\text { million units, bid) }\end{array}$ & Effective rate of treatment: $76.67 \%$ vs $46.67 \%, P<0.01$ \\
\hline Chen 2020 [14] & $\begin{array}{l}\text { Moderate COVID-19 } \\
\text { pneumonia }(n=30)\end{array}$ & RCT & $\begin{array}{l}\text { Hydroxychloroquine ( } 400, \text { qd for } 5 \text { days) } \\
\text { +Standard treatment }\end{array}$ & Standard of care & Rate of RP-PCR negative: $86.7 \%$ vs $93.3 \%, P>0.05$ \\
\hline \multicolumn{6}{|l|}{ MEDLINE } \\
\hline Cao 2020 [15] & $\begin{array}{l}\text { COVID-19 pneumonia } \\
(\mathrm{n}=199)\end{array}$ & RCT & $\begin{array}{l}\text { Lopinavir-ritonavir }(400 \mathrm{mg} / 100 \mathrm{mg} \text {, bid for } \\
14 \text { days })+ \text { Standard of care }\end{array}$ & Standard of care & $\begin{array}{l}\text { Hazard ratio for clinical improvement: } 1.24 ; \\
\text { Difference of mortality at } 28 \text { days: } 19.2 \% \text { vs. } 25.0 \% \text {, } \\
\text { P }>0.05\end{array}$ \\
\hline \multicolumn{6}{|l|}{ WHO database } \\
\hline Yuan 2020 [16] & $\begin{array}{l}\text { COVID-19 pneumonia } \\
(n=67)\end{array}$ & RCT & $\begin{array}{l}\text { Lopinavir-ritonavir combined + IFN- } \alpha+ \\
\text { Ribavirin }\end{array}$ & Lopinavir-ritonavir + IFN- $\alpha$ & $\begin{array}{l}\text { Time to RP-PCR negative and days of hospitalization: no } \\
\text { significant difference, } p>0.05\end{array}$ \\
\hline \multicolumn{6}{|c|}{ MedRxiv and BioRxiv } \\
\hline Chen 2020 [17] & $\begin{array}{l}\text { COVID-19 pneumonia } \\
(n=62)\end{array}$ & RCT & $\begin{array}{l}\text { Hydroxychloroquine }(400 \mathrm{mg} / \mathrm{d})+\text { Standard } \\
\text { of care }\end{array}$ & Standard of care & $\begin{array}{l}\text { Significant improvement in time to clinical recovery } \\
\text { (temperature recovery time and the cough remission } \\
\text { time); larger proportion of patients with improved } \\
\text { pneumonia ( } 80.6 \% \text { vs } 54.8 \% \text { ) }\end{array}$ \\
\hline Li 2020 [18] & $\begin{array}{l}\text { Mild or moderate } \\
\text { COVID-19 pneumonia } \\
(n=44)\end{array}$ & RCT & $\begin{array}{l}\text { Group 1: Lopinavir-ritonavir ( } 400 \mathrm{mg} / 100 \\
\text { mg, bid for } 7-14 \text { days) } \\
\text { Group 2: Umifenovir (200mg, tid for 7-14 } \\
\text { days) }\end{array}$ & $\begin{array}{l}\text { Standard of care with no antiviral } \\
\text { medicine }\end{array}$ & $\begin{array}{l}\text { No significant difference in median time of positive-to- } \\
\text { negative conversion of SARS-CoV- } 2 \text { nucleic acid ( } 8.5 \text { vs } 7 \\
\text { vs } 4, P=0.751 \text { ); No statistical differences in the rates of } \\
\text { antipyresis, cough alleviation, improvement of chest CT } \\
\text { or the deterioration rate of clinical status (all } P>0.05 \text { ) }\end{array}$ \\
\hline Chen 2020 [19] & $\begin{array}{l}\text { COVID-19 pneumonia } \\
(\mathrm{n}=236)\end{array}$ & RCT & $\begin{array}{l}\text { Favipiravir (Day1: } 1600 \mathrm{mg} \text {, bid; following } \\
\text { days: } 600 \mathrm{mg} \text {, bid) + Standard of care }\end{array}$ & $\begin{array}{l}\text { Umifenovir }(200 \mathrm{mg}, \mathrm{tid})+ \\
\text { Standard of care }\end{array}$ & $\begin{array}{l}\text { Moderate patients: significant improvement in clinical } \\
\text { recovery rate of day } 7(71.43 \% \text { vs } 55.86 \%, P=0.0199) \text {; } \\
\text { Significant fever reduction and cough relief }(P<0.001) \text {; } \\
\text { More adverse events ( } 13.79 \% \text { vs } 2.50 \%, P<0.0001)\end{array}$ \\
\hline
\end{tabular}

.

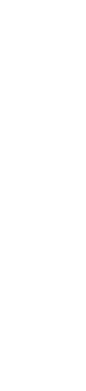

.

.

.


The standard of care followed the guidance of the "Diagnosis and Treatment Protocol for COVID-19 Pneumonia" published by the Chinese National Health Commission [39].
Nucleic acid negativity is defined by reverse transcription polymerase chain reaction (RT-PCR)

The standard of care followed the guidance of the "Diagnosis and Treatment Protocol for COVID-19 Pneumonia" published by the Chinese National Health Commission [39].
Nucleic acid negativity is defined by reverse transcription polymerase chain reaction (RT-PCR)

Rate of composite adverse outcomes is defined as $\mathrm{SpO2}<=93 \%$ without oxygen supplementation, or PaO2/FiO2 $<=300 \mathrm{mmHg}$, or respiratory rate (RR) $<=30$ breaths per minute

Time to clinical recovery is defined as the normal body temperature (underarm temperature $<=36.9$ degrees $C$ ) and cough relief (evaluated by the cough symptom score scale) in the duration of at least 72 hours from

the start of study treatment

RCT: Randomized clinical trial; COVID-19: Coronavirus Disease 2019; NA: Not available; qd: Once a day; bid: twice daily; tid: three times a day; CT: computed tomography; SARS-CoV: Severe acute respiratory

syndrome-related coronavirus

Preprints (www.preprints.org) | NOT PEER-REVIEWED | Posted: 16 April $2020 \quad \underline{\text { doi:10.20944/preprints202004.0279.v1 }}$

(a)

(1)
(1) 
Table 14 Published results of observational studies conducted in China

\begin{tabular}{|c|c|c|c|c|c|}
\hline Author year & $\begin{array}{l}\text { Population (number of } \\
\text { patients) }\end{array}$ & Study design & Intervention/Exposure (dosing, if available) & $\begin{array}{l}\text { Comparator/Reference (dosing, if } \\
\text { available) }\end{array}$ & Primary outcomes \\
\hline \multicolumn{6}{|l|}{ CNKI } \\
\hline Shi 2020 [20] & $\begin{array}{l}\text { COVID-19 pneumonia } \\
(n=49)\end{array}$ & Cohort study & $\mathrm{TCMs}+\mathrm{WMs}$ & WMs & $\begin{array}{l}\text { Significant differences in hospitalization days and } \\
\text { clinical symptom score }(P<0.05)\end{array}$ \\
\hline Xia 2020 [21] & $\begin{array}{l}\text { COVID-19 pneumonia } \\
(n=52)\end{array}$ & Cohort study & $\mathrm{TCMs}+\mathrm{WMs}$ & WMs & $\begin{array}{l}\text { Significant improvement in clinical syndrome, cure } \\
\text { rate, hospitalization time }(P<0.05)\end{array}$ \\
\hline Qu 2020 [22] & $\begin{array}{l}\text { COVID-19 pneumonia } \\
(n=70)\end{array}$ & Cohort study & $\begin{array}{l}\text { Shu-Feng-Jie-Du Capsule (2.08g, tid, } 10 \\
\text { days) + Umifenovir }(0.2 \mathrm{~g} \text {, tid) }\end{array}$ & Umifenovir $(0.2 \mathrm{~g}, \mathrm{tid})$ & $\begin{array}{l}\text { Significant differences in symptom improvement }(\mathrm{P}< \\
0.05) \text {; Significant differences in negative conversion } \\
\text { time }(\mathrm{P}<0.05)\end{array}$ \\
\hline Chen 2020 [23] & $\begin{array}{l}\text { COVID-19 pneumonia } \\
(n=134)\end{array}$ & Cohort study & $\begin{array}{l}\text { Group 1: Lopinavir-ritonavir ( } 400 \mathrm{mg} / 100 \\
\text { mg, bid, } 5 \text { days) + interferon- } \alpha 2 b+\text { symtom } \\
\text { treatment }(n=52) \\
\text { Group 2: Umifenovir ( } 200 \mathrm{mg} \text {, tid, } 5 \text { days) + } \\
\text { interferon- } \alpha 2 b+\text { symtom treatment ( } n=34 \text { ) }\end{array}$ & $\begin{array}{l}\text { Interferon- } \alpha 2 b+\text { symptom } \\
\text { treatment }(n=48)\end{array}$ & $\begin{array}{l}\text { Rate of RP-PCR negative: } 71.8 \% \text { vs } 82.6 \% \text { vs } 77.1 \%, P= \\
0.79 \text {; Number of patients of CT after } 7 \text { days treatment } \\
\text { still in progress: } 22 \text { vs } 13 \text { vs } 25, P=0.3\end{array}$ \\
\hline Cheng 2020 [24] & $\begin{array}{l}\text { COVID-19 pneumonia } \\
(n=54)\end{array}$ & Case series & $\begin{array}{l}\text { Lian-Hua-Qing-Wen (1 pack, tid) + } \\
\text { conventional treatments }\end{array}$ & NA & $\begin{array}{l}\text { The days of symptoms disappearance } \\
\text { in fever, weakness, and cough was } 3.6 \pm 2.14 \text { days, } 4 \text {. } \\
1 \pm 2.58 \text { days, and } 5.3 \pm 2.63 \text { days; The rate of } \\
\text { symptoms disappearance in the chest stuffiness, the } \\
\text { dyspnea and the moist crackles was } 84.6 \%, 100 \% \text { and } \\
89.5 \% \text {; The total efficiency was up to } 81.6 \% \text { without } \\
\text { any observed side effects by the seventh day. }\end{array}$ \\
\hline Lu 2020 [25] & $\begin{array}{l}\text { COVID-19 pneumonia } \\
(n=101)\end{array}$ & Case series & $\begin{array}{l}\text { Lian-Hua-Qing-Wen Granules (6g, tid) + } \\
\text { Standard of care }\end{array}$ & NA & $\begin{array}{l}\text { Remission rate of fever: } 86.7 \% \text { vs. } 67.6 \%, P=0.03 \\
\text { Remission rate of cough: } 55.6 \% \text { vs. } 30.6 \%, P=0.02 \\
\text { Remission rate of fatigue: } 82.5 \% \text { vs. } 58.6 \%, P=0.03 \\
\text { Remission rate of dyspnoea: } 68.2 \% \text { vs. } 20 \%, P=0.002 \\
\text { Duration of fever: } 6 \text { days vs. } 7 \text { days, } P=0.17\end{array}$ \\
\hline Yao 2020 [26] & $\begin{array}{l}\text { COVID-19 pneumonia } \\
(n=21)\end{array}$ & Case series & $\begin{array}{l}\text { Lian-Hua-Qing-Wen Granules + Standard of } \\
\text { care }\end{array}$ & NA & $\begin{array}{l}\text { Remission rate of fever } 85 .: \% \text { vs. } 57.1 \%, \mathrm{P}=0.04 \text {; } \\
\text { cough: } 46.7 \% \text { vs. } 5.6 \%, \mathrm{P} 1 / 40: 01 ; \text { Remission rate of } \\
\text { expectoration: } 64.3 \% \text { vs. } 9.1 \% \text {, } \mathrm{P}=0.01 \text {; Remission rate } \\
\text { of shortness of breath: } 77.8 \% \text { vs. } 0, \mathrm{P}=0: 02 \text {; Duration } \\
\text { of fever: } 4.6 \pm 3.2 \text { vs. } 6.1 \pm 3.1 \text { days, } \mathrm{P}=0.22\end{array}$ \\
\hline $\begin{array}{l}\text { National } \\
\text { Administration of } \\
\text { Traditional Chinese } \\
\text { Medicine, } 2020 \text { [27] }\end{array}$ & $\begin{array}{l}\text { COVID-19 pneumonia } \\
(n=214)\end{array}$ & Case series & $\begin{array}{l}\text { Qing-Fei-Pai-Du Decoction + Standard of } \\
\text { care }\end{array}$ & NA & Effective rate: $90 \%$; Improvement in radiology:60\% \\
\hline $\begin{array}{l}\text { Guangdong Medical } \\
\text { Products } \\
\text { Administration, } 2020\end{array}$ & $\begin{array}{l}\text { COVID-19 pneumonia } \\
(n=50)\end{array}$ & Case series & $\begin{array}{l}\text { Tou-Jie-Qu-Wen Granules + Standard of } \\
\text { care }\end{array}$ & NA & $\begin{array}{l}\text { Remission rates of cough: } 50 \% \text {; Remission rates of } \\
\text { sore throat: } 52.4 \% \text {; Remission rates of fatigue: } 69.6 \%\end{array}$ \\
\hline
\end{tabular}




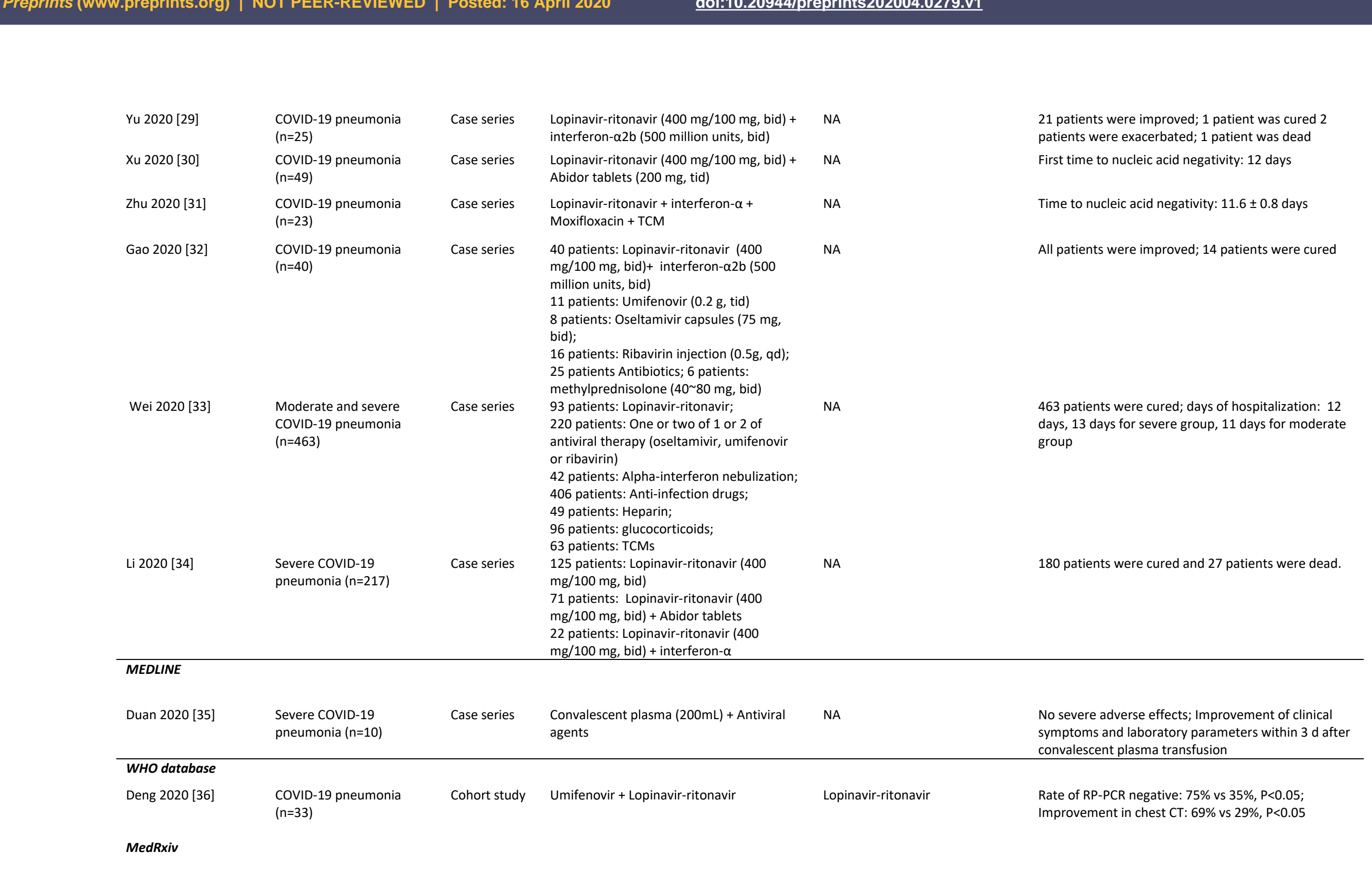

MedRxiv

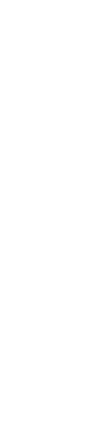




\begin{tabular}{|c|c|c|c|c|c|}
\hline Bian 2020 [37] & $\begin{array}{l}\text { COVID-19 pneumonia } \\
(\mathrm{n}=28)\end{array}$ & Cohort study & $\begin{array}{l}\text { Meplazumab ( } 10 \mathrm{mg} \text { on day } 1 \text {, day } 2 \text { and } \\
\text { day } 5)+ \text { Standard of care }\end{array}$ & Standard of care & $\begin{array}{l}\text { Significant improvement in the discharged ( } \mathrm{p}=0.006) \\
\text { and case severity }(\mathrm{p}=0.021) \text { in critical and severe } \\
\text { patients; Significant reduce in the time to virus } \\
\text { negative }(\mathrm{p}=0.014) ; \text { Improvement in the percentages } \\
\text { of patients recovered to the normal lymphocyte count } \\
\text { and CRP concentration; No adverse events }\end{array}$ \\
\hline
\end{tabular}

The standard of care followed the guidance of the "Diagnosis and Treatment Protocol for COVID-19 Pneumonia" published by the Chinese National Health Commission [39].

Nucleic acid negativity is defined by reverse transcription polymerase chain reaction (RT-PCR)

Rate of composite adverse outcomes is defined as SpO2 $<=93 \%$ without oxygen supplementation, or PaO2/FiO2 $<=300 \mathrm{mmHg}$, or respiratory rate (RR) $<=30$ breaths per minute

Time to clinical recovery is defined as the normal body temperature (underarm temperature $<=36.9$ degrees $\mathrm{C}$ ) and cough relief (evaluated by the cough symptom score scale) in the duration of at least 72 hours from the start of study treatment

TCMs: Traditional Chinses medicines; WMs : Western medicines; RCT: Randomized clinical trial; COVID-19: Coronavirus Disease 2019; NA: Not available; qd: Once a day; bid: twice daily; tid: three times a day; CT:

computed tomography 